21-23JUN

2017

23

jornadas archivos universitarios

Universidade da Coruña

Conferencia de archiveros universitarios

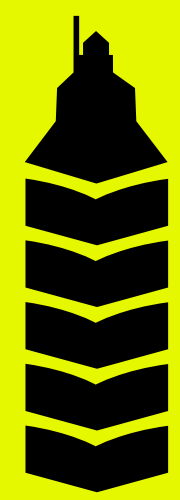





\section{El archivo electrónico en la administración digital}

23 Jornadas de Archivos Universitarios

21-23 de junio de 2017, A Coruña

Centro de Documentación e Arquivo

Servizo de Publicacións

Universidade da Coruña 
El archivo electrónico en la administración digital: 23 Jornadas de Archivos Universitarios, 21-23 de junio de 2017, A Coruña

José Luis Mínguez Goyanes, Llarina González Solar, José Felipe Fernández López (eds.)

A Coruña, 2018

Universidade da Coruña, Servizo de Publicacións

129 páginas

$15 \times 21 \mathrm{~cm}$

Índice.

ISBN: 978-84-9749-680-3

DOI: https://doi.org/10.17979/spudc.9788497496803

CDU : 930.251:004 35:004 342.9:004

\section{Edición}

Universidade da Coruña, Servizo de Publicacións <www.udc.gal/publicacions>

(C) de la edición, Universidade da Coruña

(C) de los textos, los autores

(C) de las imágenes y fotografías, sus propietarios

Diseño de cubierta: Julia Núñez Calo

Maquetación: Llarina González Solar 


\section{Índice}

Prólogo

JULIO ABALDE

Presentación

José LuIs MíNGUEZ GoyANES

\section{Comunicaciones}

Los archivos electrónicos en el ecosistema jurídico-administrativo

F. JAVIER SANZ LARRUGA

Documentos en contexto: las nuevas normas de descripción archivística y su aplicación en la administración digital JAVIER REQUEJO ZALAMA

ARPAD: el proyecto de archivo electrónico de Galicia

SABEla PILLADO QuinTÁNS y GABRIEL QUIROGA BARRO

Políticas e práticas de gestão de documentos eletrónicos na Administração: o que está mudando em Portugal

PEDRo PENTEADO

Cuánto cuesta conservar documentos electrónicos: ¿Es posible saberlo? 
Gestión integral del ciclo de vida del expediente y documento electrónico para cumplir con las leyes 39 y 40/2015

JoSÉ ÁNGEL FERNÁNDEZ CARRASCO

El papel del archivero frente a la Ley 39/2015: el documento electrónico y su implantación en una universidad: planificación, ejecución y herramientas

RAÜL RABIONET I JANSSEN

Transición real(ista) al archivo electrónico con Ricoh

MÒNICA SANYER GONZÀLEZ

Alejandría: archivo electrónico y físico integrado desarrollado para universidades

NiCOLÁS MANERo CARBÓ

El archivo como pilar del ciclo de vida del documento electrónico.

Experiencia de Informática El Corte Inglés

CARlota Tortosa Gil

Preservación de activos digitales: el seguro digital definitivo ROBERTO GONZÁLEZ SIGUERO 


\section{Prólogo}

\section{Julio Abalde}

REITOR DA UNIVERSIDADE DA CORUÑA

La Conferencia de Archiveros de las Universidades Españolas (CAU) y la Universidade da Coruña organizaron conjuntamente las 23 Jornadas de Archivos Universitarios, que se desarrollaron en A Coruña entre los días 21 y 23 de junio de 2017.

El tema escogido para esta edición de las jornadas fue El archivo electrónico en la administración digital. La actualidad e importancia de la cuestión es indiscutible, toda vez que, la publicación de las leyes 39 y 40 de 2015 implica implantar de iure la administración digital y el archivo electrónico, al establecer que la actuación normal de las administraciones públicas se soportará en documentos y expedientes electrónicos.

El reto que nos corresponde ahora a todas las administraciones -en nuestro caso, a las universidades- es lograr la implantación real de la administración electrónica, viendo en ella un elemento esencial para la prestación de un servicio público moderno y de calidad. Para ello, además de recursos informáticos, es necesario establecer un modelo de gestión documental efectivo que garantice, desde el momento mismo de la creación de los documentos, su accesibilidad, seguridad, integridad, autenticidad y fiabilidad, tanto a corto como a largo plazo. Tal como se expuso a lo largo de las jornadas, los archivos están llamados a desempeñar una función importante en el establecimiento y ejecución del modelo de gestión documental de cada institución. 
La publicación en forma de libro de las ponencias y experiencias presentadas en estas jornadas es una novedad de esta edición celebrada en A Coruña. Se busca ofrecer la mayor difusión posible a las ideas y soluciones presentadas y reforzar su conocimiento y utilidad para los profesionales de los archivos e industrias conectadas. La elección del repositorio de la UDC como plataforma de difusión garantiza la preservación y la visibilidad de los once textos presentados.

Para terminar, quiero dar las gracias a la CAU por la confianza depositada en la Universidade da Coruña y a todos los y las profesionales de los archivos que nos honraron con su presencia, con el deseo de que su participación en estas 23 Jornadas les haya sido grata y enriquecedora. 


\section{Presentación \\ José Luis Mínguez Goyanes}

UNIVERSIDADE DA CORUÑA SERVICIO DE REGISTRO, DOCUMENTACIÓN Y ARCHIVO

Las jornadas que patrocina todos los años la Conferencia de Archiveros de las Universidades Españolas (CAU) son un punto de encuentro de los archivos universitarios españoles. La CAU es la entidad que agrupa a los archiveros de las universidades, con la finalidad de colaborar en tareas y objetivos que lleven a mejorar la gestión del patrimonio documental de los centros españoles de educación superior. Estos encuentros anuales, que se vienen organizando desde 1994, son una buena muestra de cooperación archivística.

Las 23 Jornadas de Archivos Universitarios se celebraron del 21 al 23 de junio de 2017 en la Universidade da Coruña, bajo el lema de "El Archivo Electrónico en la Administración Digital". Era la primera vez que este evento tenía lugar en Galicia. Asistieron a las jornadas archiveros pertenecientes a 37 universidades españolas.

Cuando se planteó en el comité ejecutivo de la CAU la temática de las 23 jornadas tuvimos claro que tenía que ser el archivo electrónico. Era un tema que venía dado por la Ley 39/2015, de 1 de octubre, del Procedimiento Administrativo Común de las Administraciones Públicas, que insta a que las administraciones mantengan lo que denomina un archivo electrónico único de los documentos electrónicos que correspondan a procedimientos administrativos finalizados. 
Como se puede suponer la implantación de un archivo electrónico único en una administración no es una tarea fácil. Son muchos los obstáculos a los que hay que hacer frente. La normativa indica que se tiene que garantizar la autenticidad, integridad y conservación de los documentos, además de su consulta con independencia del tiempo transcurrido desde su emisión. Hay que asegurar que estos sean legibles en el futuro, lo cual implica la necesidad de luchar contra la obsolescencia digital. Hay que asegurar también que los datos se puedan trasladar a otros formatos y soportes, para garantizar a lo largo del tiempo la lectura y acceso desde diversas aplicaciones.

La Ley 39/2015 dice que una "administración sin papel” servirá mejor a los principios de eficacia y eficiencia, al ahorrar costes a ciudadanos y empresas, y además reforzará las garantías de los interesados y facilitará el cumplimiento de las obligaciones de transparencia, lo cual no es un asunto menor.

Se ha señalado el cambio de paradigma que se produce con el advenimiento de la administración electrónica. La administración no podía mantenerse al margen de la revolución que implica el mundo digital, que para algunos sería la tercera revolución industrial, marcada por la llegada de la electrónica y la tecnología de la información y las telecomunicaciones. Aunque también es cierto que otros dicen que en realidad estamos en el paso a la cuarta revolución industrial, que no estaría definida sólo por las nuevas tecnologías sino por la transición hacia nuevos sistemas construidos sobre la infraestructura que proporcionan estas tecnologías.

En las jornadas se señaló que la administración electrónica está en el núcleo duro del derecho administrativo y no puede haber una buena gestión documental sino hay un buen enlace con la fase de archivo. La 
administración electrónica y la preservación del documento tienen que estar ligadas. Y hay que tender a una sola estrategia integrada, que contemple el desarrollo de la administración electrónica, a la vez que la preservación del documento electrónico.

\section{冰冰冰水}

Una vez determinada la temática general de las jornadas había que acometer su diseño completo. Pensamos que en primer lugar se debía ubicar el marco jurídico en el que se desenvuelve el archivo electrónico, dentro de la abundante normativa que ha surgido de un tiempo a esta parte sobre administración electrónica. A continuación se contemplaron distintas experiencias: en la administración central, en la administración autonómica y en un país cercano a nosotros como es Portugal. Como remate de las ponencias pensamos que la última intervención debía versar sobre el coste de la implantación del archivo electrónico. Para hablar de todo esto requerimos el concurso de una serie de expertos, todos ellos profesionales reconocidos en el sector.

Es tradición que en las jornadas de la CAU participen empresas, que son patrocinadoras de las mismas. En las jornadas de A Coruña se contó con el concurso de doce empresas relacionadas con el mundo de la documentación (Guadaltel, 4Tic, Oficina de Cooperación UniversitariaAgtic, Ricoh, Informática El Corte Inglés, Piql, Baratz, Eypar, Datalib, Odei, Grupo Toysal y Digibis).

Estos patrocinios son una muestra de la colaboración entre el sector público y privado. En el tema de la administración electrónica no estamos en competencia con la sociedad civil: tenemos que ser aliados. De algún modo trabajamos con el mismo fin y estamos en el mismo campo. 
Las empresas optaron por diferentes modalidades de colaboración. Unas realizaron presentaciones en las que tuvieron la oportunidad de mostrar sus experiencias y las novedades en su ámbito de actuación. Otras optaron por la modalidad de un stand expositor.

Se contó también con la ayuda de siete instituciones públicas (Ministerio de Educación, Cultura y Deporte, Xunta de Galicia, Armada Española, Fundación Exponav y los ayuntamientos de A Coruña, Ferrol y Mugardos), que aportaron ayuda económica en unos casos y, en otros, colaboración con alguna de las actividades desarrolladas durante las jornadas.

En las jornadas se habló de la necesidad de llevar a cabo una política de gestión documental, en la que hay que contemplar el ciclo completo de la gestión de documentos y este ciclo termina con el archivo electrónico. En caso contrario afrontaríamos la pérdida de una importante riqueza en materia de patrimonio documental. La política de preservación implica la identificación y valoración de lo que conviene conservar.

La valoración documental forma parte de la esencia del trabajo del archivero y esto va a cambiar poco en el entorno de la administración electrónica, dado que el trabajo previo de identificar y valorar los documentos es necesario en una buena política de preservación, independientemente de que el soporte sea en papel o digital. Como se dice en las conclusiones de las jornadas en este sentido el mundo analógico y el mundo digital coinciden.

Se mencionó también la denominada "reingeniería de procesos", que busca incrementar la capacidad de gestión. La finalidad de la reingeniería es no sólo mejorar sino reinventar los procesos y, en definitiva, innovar el modo de trabajar. Implica una reconfiguración del proceso que se trate y 
tener una visión integral de la organización en la cual se desarrolla. Si bien hay que tener en cuenta que tienen que ser los procesos y no las organizaciones el objeto de la reingeniería.

En las jornadas se habló además de simplificación administrativa, de hacer un esfuerzo de coordinación y también de la conveniencia de contar con la colaboración de los ciudadanos en la mejora de acceso a los archivos e información pública.

La celebración de unas jornadas como las que estamos presentando no podría ser efectiva sin la cooperación de un buen número de personas. Por un lado, los ponentes y las personas que realizaron las presentaciones de empresa, cuyos trabajos se publican en estas páginas. Hay que mencionar por otro lado a las personas del Centro de Documentación y Archivo de la UDC (José Felipe Fernández López, Llarina González Solar) y también a los presentadores de los ponentes y exposiciones de empresa (Pepita Raventós, Pedro López, Ma José Martínez, Eva Roca, Pilar Gil, Irene Maclús) y por supuesto al comité ejecutivo de la CAU, al que tuve el honor de pertenecer durante seis años. A todos ellos, además de a las instituciones y empresas citadas, hay que agradecerles la colaboración prestada.

Es habitual que al término de las jornadas de la CAU se aprueben unas conclusiones, que vienen siendo un apretado resumen de lo tratado en ellas y sirven también para marcar unos objetivos. Terminamos esta breve presentación con ánimo de mirar hacia adelante y con el deseo de la puesta en práctica de esos objetivos. 
23

jornadas

archivos

universitarios

comunicaciones 


\title{
Los archivos electrónicos en el ecosistema jurídico-administrativo
}

\section{Francisco Javier Sanz Larruga}

\author{
UNIVERSIDADE DA CORUÑA \\ GRUPo DE INVESTIGACión DE DERECho PÚBLICo GLOBAL
}

\section{Resumen}

La nueva regulación jurídico-administrativa introducida por las leyes estatales 39 y 40 de 2015 y su incidencia sobre los archivos electrónicos es el objetivo central de este trabajo. No obstante, para conocer en profundidad el funcionamiento de dichos archivos es preciso conocer su verdadera inserción en el sistema (o ecosistema) de gestión documental tal como se regula en las referidas leyes. El futuro de los archivos digitales $-\mathrm{y}$, en particular, los de las universidades españolas- pasa por un ambicioso proceso de modernización de la gestión documental en el que deben implicarse todos los sujetos intervinientes (autoridades, archiveros, ciudadanos, etc.), así como por el replanteamiento de los procesos de documentación y archivo, con un cambio de paradigma: de la gestión electrónica de documentos a la gestión de documentos electrónicos.

Palabras clave: Archivos electrónicos; Derecho administrativo; Gestión documental

Cita recomendada: Sanz Larruga, F. J. (2018). Los archivos electrónicos en el ecosistema jurídico-administrativo. En El archivo electrónico en la administración digital: 23 Jornadas de Archivos Universitarios, 21-23 de junio de 2017, A Coruña (pp. 9-26).

DOI capítulo: https://doi.org/10.17979/spudc.9788497496803.009 DOI libro: https://doi.org/10.17979/spudc.9788497496803 


\section{Introducción: el ecosistema jurídico-administrativo de los archivos}

En el marco de las XXIII Jornadas de Archivos Universitarios -cuyo leitmotiv ha sido "El archivo electrónico en la administración digital"vamos a tratar en este trabajo de los archivos digitales desde la perspectiva jurídico-administrativa tras la reforma operada en su régimen jurídico por las leyes 39 y 40 de 2015, relativas, respectivamente, a la regulación del procedimiento administrativo común y al régimen jurídico del sector público (en adelante, LPAC y LRJSP).

Partiendo de la definición de "archivo" de la Ley 16/1985 del Patrimonio Histórico Español, es decir, como un "conjunto organizado de documentos" (cfr. art. 59.1) y utilizando simbólicamente el concepto de ecosistema de la ecología, es importante destacar que el archivo es una pieza fundamental del llamado "sistema de gestión documental" (Sanz Larruga, 2017). En efecto, como elementos básicos del sistema administrativo de gestión documental pueden distinguirse:

- los documentos, en los que se contienen los datos y la información;

- los expedientes, en los que se ordena dicha información;

- los registros, mediante los que se introduce y expide la información; y, finalmente,

- los archivos, en los que se almacena y conserva la información.

Todos estos componentes son susceptibles de desarrollarse en el ámbito de la administración electrónica (e-Administración) y, en este sentido, uno de los mejores expertos en España sobre esta materia, el profesor Julián Valero Torrijos (2013), ha afirmado que "uno de los principales desafíos para la modernización tecnológica de las Administraciones Públicas consiste en revisar el modelo de gestión documental". 
Siguiendo con el símil del ecosistema jurídico, en el que se desarrollan de manera creciente los archivos electrónicos, no debe perderse de vista que, al regularse los archivos por el Estado, su normativa se refiere al Sistema Español de Archivos (cfr. el Real Decreto 1708/2011, de 18 de noviembre). En la propia gestión de los documentos se habla del ciclo de vida del documento (es decir, las diferentes etapas por los que atraviesan los documentos desde que se producen hasta su eliminación conforme al procedimiento establecido o, en su caso, su conservación permanente). Igualmente, la importante función de la archivística en cuanto a la conservación del patrimonio documental nos recuerda uno de los objetivos básicos de la regulación del patrimonio natural y de la biodiversidad: su preservación. Por último, es indudable que una de las ventajas de la administración electrónica y, dentro de ésta, de los archivos digitales, es que permite ahorrar muchos recursos naturales y energéticos (en la senda hacia una administración sin papel).

\section{El nuevo marco jurídico-administrativo de los archivos digitales. Su carácter supletorio en las universidades públicas}

Como se ha tratado extensamente, la regulación de los archivos digitales o electrónicos es una cuestión que viene interesando no sólo a los juristas sino también a los profesionales de la archivística, en particular desde la aprobación de la Ley 11/2007, de 22 de junio, de acceso electrónico de los ciudadanos a los servicios públicos (Serra Serra, 2008; Sanz Larruga, 2010; Valcárcel Fernández, 2011). Con la aprobación de las nuevas leyes administrativas (LPAC y LRJSP) -y desde su entrada en vigor en octubre de 2016- tenemos un nuevo régimen jurídico del sistema administrativo de gestión documental (Sanz Larruga, 2017) que, en lo relativo específicamente a los archivos, se concreta en dos artículos: 
1) El artículo 17 de la LPAC sobre "archivo de documentos", cuyo contenido puede sintetizarse del siguiente modo:

a) La previsión de un novedoso "archivo electrónico único" que "cada Administración deberá mantener" en el caso de "documentos electrónicos que correspondan a procedimientos finalizados" (art. 17.1), al que, por singularidad, nos referiremos en el apartado 4 de este trabajo.

b) La obligación de conservación de los documentos electrónicos "en un formato que permita garantizar la autenticidad, integridad y conservación del documento, así como su consulta con independencia del tiempo transcurrido desde su emisión", asegurándose "en todo caso la posibilidad de trasladar los datos a otros formatos y soportes que garanticen el acceso desde diferentes aplicaciones" (art. 17.2). Y, por lo que se refiere a la "eliminación" o expurgo de los documentos, ha de "ser autorizada de acuerdo con los dispuesto en la normativa aplicable" (art. 17.2 in fine).

c) Con especial atención a la seguridad en la gestión de los documentos, el art. 17.3 exige que "los medios o soportes en que se almacenan documentos, deberán contar con medidas de seguridad, de acuerdo con lo previsto en el Esquema Nacional de Seguridad ${ }^{1}$, que garanticen la integridad, autenticidad, confidencialidad, calidad, protección y conservación de los documentos almacenados". Además, se especifica, dentro de las medidas de seguridad, "la identificación de los usuarios y el control de accesos, así como el cumplimiento de las garantías previstas en la legislación de protección de datos" (art. 17.3 in fine).

${ }^{1}$ Contenido en el Real Decreto 3/2010, de 8 de enero. 
2) El contenido del art. 46 de la LRJSP - sobre "archivo electrónico de documentos"-puede resumirse así:

a) Destaca la directriz según la cual "todos los documentos utilizados en las actuaciones administrativas se almacenarán por medios electrónicos", aunque añade una coletilla moderadora de tal exigencia: "salvo cuando no sea posible" (art. 46.1)

b) Al igual que el art. 17 de la LPAC, el apartado 2 del art. 46 incide en la necesidad de conservar en soporte electrónico o digital "los documentos electrónicos que contengan actos administrativos que afecten a derechos o intereses de los particulares"; pero la naturaleza electrónica del soporte no obsta -según el mismo art. 17.2- para que el "formato" no sólo sea el mismo "a partir del que se originó el documento", sino que puede conservarse en otros formatos con tal "que asegure la identidad e integridad de la información necesaria para reproducirlo", pero debe asegurarse "en todo caso la posibilidad de trasladar los datos y soportes que garanticen el acceso desde diferentes aplicaciones".

c) Según las definiciones contenidas en el Anexo del Esquema Nacional de Interoperabilidad (contenido en el Real Decreto 4/2010, de 8 de enero), el "soporte" es el "objeto sobre el cual o en el cual es posible grabar y recuperar datos", utilizado en el almacenaje de los documentos electrónicos, puede ser magnético (disquetes y discos duros) u ópticos (CD y DVD, con sus diversas modalidades y versiones); por su parte el "formato" es el "conjunto de reglas (algoritmo) que define la manera correcta de intercambiar o almacenar datos en memoria". Así, la información puede consistir en textos escritos, sonidos, imágenes, vídeos, páginas web, etc. que, a su 
vez, son generados y procesados por diferentes programas y aplicaciones informáticas.

d) De nuevo, empeñado en la seguridad, en el art. 46.3 se exige que "los medios o soportes en que se almacenen documentos, deberán contar con medidas de seguridad, de acuerdo con lo previsto en el Esquema Nacional de Seguridad, que garanticen la integridad, autenticidad, confidencialidad, calidad, protección y conservación de los documentos almacenados". Y, más en particular, el mismo precepto acaba disponiendo que "asegurarán la identificación de los usuarios y el control de accesos, el cumplimiento de las garantías previstas en la legislación de protección de datos, así como la recuperación y conservación a largo plazo de los documentos electrónicos producidos por las Administraciones Públicas que así lo requieran, de acuerdo con las especificaciones sobre el ciclo de vida de los servicios y sistemas utilizados".

Con relación a los anteriores preceptos rige un régimen de transitoriedad cuyas reglas pueden resumirse como sigue:

1) Para "el archivo de documentos correspondientes a procedimientos administrativos ya iniciados antes de la entrada en vigor de la presente Ley $^{2}$, se regirán por lo dispuesto en la normativa anterior" (Disposición transitoria primera), si bien la misma disposición añade en su apartado 2 que "siempre que sea posible, los documentos en papel asociados a procedimientos administrativos finalizados antes de la entrada en vigor de esta Ley, deberán digitalizarse de acuerdo con los requisitos establecidos en la normativa reguladora aplicable".

${ }^{2}$ Es decir, el 2 de octubre de 2016. 
2) En cuanto al "archivo electrónico único" en el ámbito de la "Administración General del Estado", hasta el 2 de octubre de 2017 "podrán mantenerse los archivos existentes en el momento de entrada en vigor de esta Ley" (Disposición transitoria segunda, apartado a) y, a partir del 2 de octubre de 2018, "se dispondrá como máximo (...) de un archivo electrónico por cada Ministerio" (Disposición transitoria segunda, apartado b).

3) Y, por último, tal como dispone la Disposición transitoria cuarta, "mientras no entren en vigor las previsiones relativas al (...) archivo único electrónico, las Administraciones Públicas mantendrán los mismos canales, medios o sistemas electrónicos vigentes relativos a dichas materias, que permitan garantizar el derecho de las personas a relacionarse electrónicamente con las Administraciones".

Una última, pero no menos importante, cuestión sobre el régimen de los archivos electrónicos en las nuevas leyes administrativas es la relativa a su aplicación sobre los archivos de las universidades (en particular, de las universidades públicas). Y, es que, como establece el art. 2.2.c) de la LPAC, las "Universidades públicas" -que se integran en el "sector público institucional"- "se regirán por su normativa específica y supletoriamente por las previsiones de esta Ley”. ¿Significa esta especificidad del ámbito de aplicación de la LPAC sobre las universidades públicas que no son aplicables las disposiciones que hemos visto hasta ahora sobre el archivo electrónico? Tal como comenta el profesor Amoedo Souto (2017), pese al aparente "desanclaje" de las universidades del régimen jurídico-administrativo común, la necesidad de salvaguardar a los usuarios del servicio público educativo de las garantías procedimentales comunes a las disfrutadas por los ciudadanos, no es previsible (salvo que una reforma de la Ley Orgánica 6/2001 de Universidades, desplace los preceptos de la LPAC) que haya en el 
derecho propio de las universidades una alteración de dichas garantías básicas en sus procedimientos administrativos. Por consiguiente, puede concluirse que el régimen jurídico-administrativo sobre los archivos electrónicos contenido en la LPAC y la LRJSP es aplicable con normalidad sobre el futuro régimen jurídico de los archivos electrónicos universitarios.

\section{Los archivos digitales y el sistema administrativo de gestión documental. La incidencia de las normas técnicas sobre políticas de gestión de documentos.}

Una vez analizado - de forma necesariamente breve- el nuevo régimen jurídico-administrativo de los archivos electrónicos a partir de las vigentes leyes administrativas (LPAC y LRJSP), vamos a subrayar la posición estratégica y primordial que los archivos desempeñan en el sistema administrativo de gestión documental.

Antes de entrar en esta materia, conviene hacer un repaso del contenido de su complejo "grupo normativo" ya que, en efecto, la regulación de la institución de los archivos no sólo se encuentra en las referidas leyes administrativas (los arts. 17 de la LPAC y 46 de la LRJSP, relativos exclusivamente a los "archivos electrónicos"), sino que su principal "norma de cabecera" está en la ya citada Ley 16/1985 de. Patrimonio Histórico Español. Conforme a la distribución de competencias entre el Estado y las Comunidades Autónomas (cfr. art. 149.1.28 de la Constitución Española de 1978), éstas han regulado el respectivo régimen jurídico de los archivos de los que son competentes. De otra parte, sin bajar del nivel legislativo, como el "derecho de acceso de los ciudadanos a los archivos" es un derecho expresamente contemplado en la propia 
Constitución Española (art. 105.b), es fundamental referirse a la Ley 19/2013, de transparencia, acceso a la información pública y buen gobierno (cfr. art. 13.d de la LPAC). Además, como buena parte de la información alojada en los archivos se refiere a datos de carácter personal, no hay que olvidar la vigencia de la Ley Orgánica 15/1999, de Protección de Datos de Carácter Personal (llamada a ser sustituida por el régimen jurídico del comunitario Reglamento General de Protección de Datos, que comenzará a aplicarse el 25 de mayo de 2018).

Entrando ahora en el estudio de los elementos que integran el sistema de gestión documental, nos parece que resulta de gran utilidad destacar, siempre en relación con los archivos digitales o electrónicos, lo siguiente:

1) Sobre los documentos electrónicos: como ya dijimos anteriormente, los archivos son conjuntos orgánicos de documentos $\mathrm{y}$, por consiguiente, debe conocerse el nuevo régimen jurídico de los documentos electrónicos, tanto los emitidos por las Administraciones Públicas (cfr. art. 26 de la LPAC) y de sus copias (cfr. art. 27 de la LPAC), así como los documentos aportados por los interesados al procedimiento administrativo (cfr. art. 28 de la LPAC y Sanz Larruga, 2017); conocer el concepto de documento electrónico y sus clases (públicos y privados), sus notas características, los requisitos para su validez y eficacia jurídicas (autenticidad, fiabilidad, integridad y disponibilidad), la función de los metadato ${ }^{3}$, la identificación de los autores de los documentos (certificados electrónicos y sistemas de firma electrónica), la acreditación de su referencia

\footnotetext{
${ }^{3} \mathrm{O}$ cualquier tipo de información en forma electrónica asociada a los documentos electrónicos, de carácter instrumental e independiente de su contenido, destinada al conocimiento inmediato y automatizable de alguna de sus características, con la finalidad de garantizar la disponibilidad, el acceso, la conservación y la interoperabilidad del propio documento.
} 
temporal (o sellado de tiempo), etc. Y, en cuanto a las copias de documentos electrónicos: sus modalidades, los requisitos para su válida emisión y recepción en el procedimiento (o archivo de gestión). También es imprescindible conocer la técnica de la “digitalización" de documentos o de sus copias y las condiciones para su validez.

2) Sobre los expedientes electrónicos-regulados en el art. 70 de la LPAC (cfr. Sanz Larruga, 2017)- son definidos en el apartado 1 ("el conjunto ordenado de documentos y actuaciones que sirven de antecedente y fundamento a la resolución administrativa, así como las diligencias encaminadas a ejecutarla"). Esta definición nos permite considerar que, en los archivos de gestión, la información se articula, habitualmente, en torno a procedimientos administrativos que concluyen en decisiones administrativas. Por lo tanto, los archivos electrónicos son "conjuntos ordenados de documentos electrónicos" encaminados a resolver actuaciones administrativas de variada naturaleza.

3) Sobre los registros electrónicos (cfr. art. 16 de la LPAC), constituyen también conjuntos de documentos. Son instrumentos o centros de ordenación o gestión de documentos, ya sea con la simple finalidad de controlar los documentos que entran, circulan $\mathrm{y}$ salen de los diferentes centros administrativos $\mathrm{y}$, por consiguiente, de los archivos de gestión donde se conservan.

En definitiva, de todo lo anterior se deduce con claridad que los archivos (electrónicos o no) desempeñan una función esencial en el sistema de gestión documental: almacenan y conservan ordenadamente -insertos internamente en un expediente administrativo- los documentos (privados o públicos) que se reciben a través de los registros administrativos, así como la información que se va generando en el seno de la entidad 
administrativa de la que dependen funcionalmente; y, por fin, a través de los archivos -vía también del registro de salida (por notificación o publicación)- se da a conocer la información administrativa correspondiente, resultante -habitualmente- de la terminación de un procedimiento administrativo.

Una función esencial que se lleva a cabo en los archivos administrativos es la gestión de documentos administrativos (o records management, en inglés), es el conjunto de tareas y procedimientos orientados a lograr una mayor eficacia y economía en la explotación de los documentos por parte de las administraciones públicas. Para facilitar esta tarea, se viene siguiendo una serie de instrumentos de soft law como el Modelo de Requisitos para la Gestión de Documentos Electrónicos de Archivo conocido por las siglas MoReq-, con el fin de que pueda ser utilizado por todos los países de la Unión Europea y por todos los interesados en el desarrollo y aplicación de sistemas de gestión de documentos electrónicos de archivo (archiveros, gestores, diseñadores de software, proveedores de servicios, instituciones académicas y de formación). El MoReq incidió especialmente en los requisitos funcionales de la gestión de documentos electrónicos de archivo mediante un sistema de gestión de documentos electrónicos de archivo (SGDEA). Y, como hito culminante del proceso de normalización, en 2011 se publicaron las ISO 30300, reforzando de este modo "el enfoque sistémico de la gestión de los documentos (...) facilitando la demostración del cumplimiento (compliance) de las leyes, normas y estándares que afectan al sistema" (García Morales, 2013).

Más recientemente, para la gestión de los documentos administrativos $-\mathrm{y}$ para los documentos electrónicos en particular-, los gobiernos han diseñado políticas de gestión de documentos electrónicos que están basadas en buenas prácticas y en normas técnicas consolidadas a nivel nacional e internacional. En España, la aprobación en 2010 de la 
Estrategia Nacional de Interoperabilidad (ENI) trajo consigo la elaboración de determinadas normas técnicas de interoperabilidad en el ámbito de la administración electrónica, entre las que destaca, a estos efectos, la relativa a la Política de gestión de documentos electrónicos, aprobada por la Resolución de la Secretaría de Estado de Administraciones Públicas de 28 de junio de 2012. Y, finalmente, como complemento a la repetida Norma Técnica sobre Interoperabilidad, en julio de 2012 se publicó la Guía de aplicación de la Norma Técnica de Interoperabilidad de Política de gestión de documentos electrónicos. En esta guía se describen con claridad y completitud todos los elementos que intervienen en la Política de gestión de documentos electrónicos.

\section{4. ¿Hacia el archivo electrónico único?}

Una de las novedades más significativas de las nuevas leyes administrativas, con relación a los archivos, es la referencia a un archivo electrónico único (en adelante, AEU) que ha dado lugar a una viva controversia en la doctrina archivística en torno a su significado (cfr. los trabajos de Esteve Casellas i Serra (2016), Cots (2016), Serra Serra (2016), Soler Jiménez (2016), Fernández Cuesta (2016; 2017), Nualart Mercadé (2017), Bustos Petrel (2017). En efecto, el art. 17.1 de la LPAC dispone que: "Cada Administración deberá mantener un archivo electrónico único de los documentos electrónicos que corresponden a procedimientos finalizados, en los términos establecidos en la normativa reguladora aplicable".

Como ha destacado la doctrina, del contenido de esta disposición no cabe deducir claramente el verdadero significado de este precepto $y$, por consiguiente, habrá que esperar a futuros desarrollos reglamentarios o 
mayores concreciones por el legislador. Según Bustos Pretel (2017) el AEU ha de entenderse como "un almacén único de expedientes y documentos electrónicos, donde la responsabilidad la marca en cada caso quien tiene la custodia de cada expediente"; es la idea de la "colmena": el AEU como repositorio electrónico integrado por todas las partes que sean necesarias a imagen de las celdas de la colmena, "una plataforma común con gestión única, seguridad común, acceso común y custodia descentralizada". Por su parte, Nualart Mercadé (2017) critica la distinción que se desprende del citado art. 17.1 de la LPAC en cuanto a que el AEU sólo se exige en el caso de "documentos electrónicos que correspondan a procedimientos finalizados" (no para el resto de los documentos electrónicos, por ejemplo, los que están en fase de tramitación), lo cual "rompe la concepción holística de la gestión de los documentos como un proceso continuo desde el momento de la creación documental y el archivo"; según el mismo autor, el AEU debería

Constituir un sistema de gestión de documentos y de gestión de archivos que permita la gestión, la custodia y la difusión de los documentos y expedientes una vez finalizada la tramitación administrativa hasta su disposición final, ya sea la eliminación reglada o su conservación permanente y garantizando en todo momento, la correcta asignación de las responsabilidades, en cuanto a su gestión y custodia, por parte de los archivos correspondientes.

También Serra Serra (2016) se muestra crítico con la formulación del AEU ya que "constituye una evidente regresión hacia un concepto arcaico de la función de archivo, reviviendo la confusión entre archivo y depósito", "una visión excesivamente clásica de la nueva Ley, reincidente en el error de trasladar al entorno electrónico conceptos propios del mundo papel sin una reflexión profunda de sus implicaciones...”. El mismo autor destaca, por el contrario, que "un archivo es la 
materialización de una obligación de conservación y su configuración como servicio, servicio que se dota, entre otros recursos, de los depósitos físicos o digitales que sean necesarios...". En todo caso, esta dificultad interpretativa sobre el significado del AEU "nos augura un nuevo periodo de debates interpretativos sobre cómo dar cabida jurídica a las nuevas posibilidades para la gestión administrativa que la evolución tecnológica nos ofrece".

Por último, Cots (2016) afirma que:

La clave en la definición del archivo electrónico único no la hallaremos en el art. 17 de la LPAC ni en el art. 46 de la LRJSP, sino en todo el contenido propio de la Ley y su apuesta preceptiva por el expediente electrónico, que requerirá de reingeniería de los procesos, la incorporación de metadatos obligatorios, la clasificación funcional, el cuadro de tipos documentales, etc., y ello, ¿por qué? Pues porque el archivo interviene desde el inicio del ciclo de vida de los documentos y procedimientos, y porque una vez definidos los documentos hay que asociar los metadatos mínimos obligatorios y complementarios a cada documento y procedimiento a lo largo del ciclo de vida de éste, para garantizar la autenticidad, la integridad y la conservación del documento, así como su consulta independientemente del tiempo transcurrido desde que se emitió.

En definitiva, pese a las dudas interpretativas que ahora planean sobre el concepto de AEU, la informatización plena y universal del procedimiento administrativo (que promueven las nuevas leyes administrativas) ha de llevar, tarde o temprano, a una clarificación del papel esencial de los archivos en la política de gestión documental, a una más armónica interrelación de los elementos que la componen, y a una simplificación de las funciones que desempeñan los archivos. 


\section{Reflexiones finales}

El impulso dado por las nuevas leyes administrativas (LPAC y LRJSP), que sitúan en el corazón de la reforma a la administración electrónica, es una inmejorable oportunidad para llevar a cabo una profunda reforma en la gestión documental y archivística.

Tan ambicioso objetivo - que redundará en una mejor administración y en un mejor servicio a los ciudadanos- sólo se logrará mediante un esfuerzo colectivo: de coordinación administrativa, de colaboración públicoprivada, de colaboración de los ciudadanos en la mejora de acceso a los archivos e información pública, etc. Una buena muestra de este esfuerzo colectivo, dentro del campo de actuación de las universidades, es el Convenio Marco de colaboración entre la Administración General del Estado (MINHAP) y la CRUE Universidades Españolas para la prestación mutua de soluciones básicas de administración electrónica, de 20 de julio de 2016 .

Para lograr una administración sin papeles resulta imprescindible un buen sistema de gestión documental electrónico -ágil, accesible, transparente y valioso-, que tenga como punto de arranque una buena política de gestión de documentos y como punto de destino el archivo electrónico. Un sistema coherente en el que se respete el principio de continuidad de la gestión documental y la fase de archivo, y donde se cuide el buen funcionamiento y el cuidado de todos sus elementos (datos y metadatos, documentos, registros, expedientes, etc.). Un sistema en que el archivo no sea una tumba de documentos, sino que esté llamado a ser, en muchos casos, un tesoro informacional y una mina de información (big data). 
En todo caso, para el cambio de paradigma que se pretende - de la gestión electrónica de documentos a la gestión de documentos electrónicos- es clave la formación de los recursos humanos, preparados para un trabajo interdisciplinar (archiveros y documentalistas, ingenieros informáticos, juristas, etc.) y con una decidida implicación de los responsables públicos. También es imprescindible en tan necesario cometido la innovación, la reingeniería tanto de los procesos como de la organización, aprendiendo siempre de las buenas prácticas.

Como reza la Managing Government Records Directive de 2012, resultante de un memorándum del presidente Obama (citado por GarcíaMorales, 2013)

Los documentos son la base y el fundamento de un gobierno abierto y el soporte de los principios de transparencia, participación y colaboración. Los documentos bien gestionados se pueden utilizar para evaluar el impacto de los programas, para mejorar los procesos de trabajo y para compartir conocimientos entre instancias del gobierno. Los documentos protegen los derechos e intereses de los ciudadanos y hacen a los funcionarios responsables de sus acciones. Los documentos permanentes documentan la historia de nuestra nación.

\section{Bibliografía}

Amoedo Souto, C. (2017). El impacto de las Leyes 39 y 40/2015 en las Universidades Públicas: contenido, hipótesis y retos de futuro. Revista Española de Derecho Administrativo, 182, 283-312.

Bustos Petrel, G. (2017). "Archive" y punto final. Consultor de los ayuntamientos y de los juzgados: Revista técnica especializada en administración local y justicia municipal, 5, 684-691. 
Cots, R. (2016). El archivo electrónico único: el problema conceptual como reto y no como dificultad y su sostenibilidad. Consultor de los ayuntamientos y de los juzgados: Revista técnica especializada en administración local y justicia municipal, 24, 2783-2784.

Esteve Casellas i Serra, L. (2016). El archivo electrónico único, una visión sesgada. Consultor de los ayuntamientos y de los juzgados: Revista técnica especializada en administración local y justicia municipal, 24, 2785-2788.

Fernández Cuesta, F. (2017). Valoración funcional y macrovaloración en el contexto del archivo electrónico único. Archivamos: Boletín ACAL, 103, 4345.

Fernández Cuesta, F. (2017). Un mar de preguntas sobre el archivo electrónico único: (a propósito de un artículo de Gerardo Bustos). Archivamos: Boletín ACAL, 104, 38-40.

Fernández Cuesta, F. (2016). Un archivo único para gobernarlos a todos: el tortuoso camino hacia el Monte del Destino de los documentos electrónicos. Archivamos: Boletín ACAL, 99, 39-41.

García Morales, E. (2013). Gestión de documentos en la e-Administración. Barcelona: Universitat Oberta de Catalunya.

Nualart Mercadé, R. (2017). Innovación en el ámbito de la preservación digital y archivo electrónico único. Consultor de los ayuntamientos y de los juzgados: Revista técnica especializada en administración local y justicia municipal, 7, 944-958.

Sanz Larruga, F. J. (2017). Gestión documental. En S. Fernández Ramos, J. Valero Torrijos y E. Gamero Casado (coord.), Tratado de Procedimiento Administrativo Común y Régimen Jurídico Básico del Sector Público (vol. 1(1), pp. 913-995). Valencia: Tirant lo Blanch.

Serra Serra, J. (2008). Los documentos electrónicos. Cómo son y cómo se tratan. Oviedo: Trea.

Serra Serra, J. (2016). El archivo electrónico único en la Ley 39/2015: ¿una oportunidad... perdida?. Consultor de los ayuntamientos y de los juzgados: 
Revista técnica especializada en administración local y justicia municipal, 24, 2788-2791.

Soler Jiménez, J. (2016). La hora de la verdad: el archivo electrónico único. Consultor de los ayuntamientos y de los juzgados: Revista técnica especializada en administración local y justicia municipal, 24, 2781-2782.

Valcárcel Fernández, P. (2011). Documentos y archivos electrónicos. En J. L. Piñar Mañas (dir.) Administración electrónica y ciudadanos (pp. 531-631). Cizur Menor: Civitas-Thomson Reuters.

Valero Torrijos, J. (2013). Derecho, innovación y administración electrónica. Sevilla: Global Law Press. 


\section{Documentos en contexto: las nuevas normas de descripción archivística y su aplicación en la administración digital}

\section{Javier Requejo Zalama}

Ministerio de Educación, Cultura y Deporte SUbDIRECCIÓN GENERAL DE ARCHIVOS ESTATALES

\section{Resumen}

A partir de una reflexión inicial sobre el origen del proceso de normalización de la descripción archivística en España, se realiza una somera presentación de las principales normas de descripción desarrolladas a lo largo de los últimos 20 años. Se analiza la compleja relación entre ellas, especialmente en los actuales entornos de administración electrónica, donde prácticamente ninguna de las normas vigentes hasta el año 2015 era capaz de ofrecer una solución integral para todo el proceso descriptivo.

Esta reflexión se acompaña de una presentación de las últimas normas sobre la materia, especialmente de los modelos conceptuales de descripción archivística: NEDA-MC, concebido como norma española de descripción archivística y aprobado en 2017, y RiC-CM, de carácter internacional y todavía en fase de borrador. Ambas buscan solventar los problemas existentes puesto que identifican las entidades básicas a describir y las posibles relaciones entre ellas, concebidos ambos elementos como generadores del contexto informativo. Con ello, se erigen en unas nuevas normas para diseñar los sistemas de descripción, logrando la compatibilidad entre los diversos desarrollos normativos. 
Palabras clave: Descripción; Normalización; Norma Española de Descripción Archivística; Sistemas de descripción; Contexto documental

Cita recomendada: Requejo Zalama, J. (2018). Documentos en contexto: las nuevas normas de descripción archivística y su aplicación en la administración digital. En El archivo electrónico en la administración digital: 23 Jornadas de Archivos Universitarios, 21-23 de junio de 2017, A Coruña (pp. 27-41).

DOI capítulo: https://doi.org/10.17979/spudc.9788497496803.027

DOI libro: https://doi.org/10.17979/spudc.9788497496803

La descripción es un proceso de larga tradición en el ámbito de la gestión documental, prácticamente inherente a la propia historia de la gestión de los documentos. Ahora bien, la normalización de dicho proceso, entendida como la adopción de reglas comunes para llevar a cabo el proceso descriptivo, tiene un origen bastante más reciente. Y precisamente los avances en materia de descripción archivística han evolucionado tan rápido en las últimas décadas, que las normas para describir no eran capaces de dar una respuesta eficaz a las necesidades que planteaban esos nuevos entornos evolucionados.

\section{Análisis preliminar de la realidad normativa}

Para poder comprender el enorme avance que la descripción archivística ha experimentado en los últimos años, es preciso identificar el punto de origen del proceso normalizador. En el caso español, ese momento lo podemos situar en la década de los años 90 del pasado siglo XX, cuando 
la descripción en archivos venía manteniendo un modelo tradicional de descripción, asentado en una serie de prácticas que habían resultado de suma utilidad durante mucho tiempo. Incluso en determinados sectores se habían llegado a considerar normas de facto para describir como, por ejemplo, la identificación de las guías, inventarios y catálogos como instrumentos básicos para describir en archivos.

Es en esta década de los años 90 cuando la normalización se empieza a hacer efectiva a nivel global, con el primer gran proyecto de creación de una norma para describir en archivos a nivel internacional. Ese proyecto, si bien no llegó a cristalizar de forma efectiva hasta el año 2000 con la adopción de la segunda versión de $\operatorname{ISAD}(\mathrm{G})$, fue desarrollado durante la década anterior y llevó aparejado un impulso colectivo por adaptarse a la nueva situación.

Es en esa época cuando nace el espíritu normalizador en materia de descripción, resultando particularmente interesante analizar cómo ese proceso regulador surge en una etapa concreta de los archivos. También los archiveros y archiveras presentaban unas características definitorias muy específicas y ajustadas a esa época en concreto. Todos han sufrido una enorme actualización. Es el caso, por ejemplo, de la aparición de la administración electrónica, que ni siquiera era concebida como una posibilidad real en la década de los años 90 .

Esta situación inicial fue evolucionando en los años posteriores, momento en que se produce la consolidación de la descripción normalizada. En los quince primeros años del siglo XXI se produce el gran salto que abre un nuevo escenario para la gestión documental: la irrupción general de lo digital y, en particular, de la administración electrónica. Es precisamente con este salto cuando empiezan a plantearse las primeras cuestiones o dudas sobre las normas desarrolladas, pues estas no son capaces de 
ofrecer una solución a las nuevas coyunturas planteadas y se proponen soluciones específicas para darles respuesta ${ }^{4}$.

Además, el desarrollo de este nuevo entorno se apoyó en un cambio generacional, con la llegada al mundo de la gestión documental de un equipo de profesionales que tenían un mayor conocimiento sobre el uso de las tecnologías de información. Esto facilitó la aparición de ciertos estándares sectoriales, que pretendían resolver la carencia que la normalización inicial presentaba en esta nueva realidad. E incluso, en algunos de estos desarrollos sectoriales se puede llegar a atisbar lo que vendrá a ser el nuevo paradigma de la descripción archivística.

Lo cierto es que, en estos años de consolidación, la normalización de la descripción archivística eclosiona con la aparición, casi exponencial, de múltiples normas para describir, planteadas desde múltiples perspectivas:

- Según el objetivo de la norma, es posible clasificarlas de la siguiente manera:

- Estándares para identificar el contenido a describir (Tabla 1).

- Estándares para identificar la estructura de los datos (Tabla 2).

- Según el ámbito de aplicación de la norma es posible clasificarlas:

○ Estándares globales, de aplicación en cualquier entorno (cfr. Tabla 3).

- Estándares sectoriales, de aplicación limitada a determinados sectores territoriales, institucionales o administrativos (cfr. Tabla 4).

\footnotetext{
${ }^{4}$ Ninguna de las normas actuales adoptadas por el Consejo Internacional de Archivos (ISAD $(\mathrm{G})$, ISAAR(CPF), ISDF e ISDIAH) fueron concebidas para identificar campos o metadatos descriptivos, por lo que resultaban normas "inútiles" para diseñar sistemas de descripción. Hubo, por tanto, que plantearse requisitos funcionales específicos para crear aplicaciones informáticas de gestionar metadatos.
} 
Tabla 1. Normas de descripción de contenido

\begin{tabular}{lll} 
Objeto a describir & Estándares globales & Estándares sectoriales \\
\hline Documentos & ISAD(G) & MDM \\
& & NOGADA \\
& & NODAC \\
\multirow{2}{*}{ Agentes } & ISAAR(CPF) & ARANOR \\
& ISDIAH & \\
Funciones & ISDF &.-- \\
\hline
\end{tabular}

Tabla 2. Normas de descripción de estructura

\begin{tabular}{lll} 
Objeto a describir & Estándares globales & Estándares sectoriales \\
\hline Documentos & EAD & EMCAU \\
& & EDARA \\
& & VMGC \\
& & e-EMGDE \\
Agentes & EAC & e-EMGDE \\
& EAG & \\
Funciones &.-- & e-EMGDE \\
\hline
\end{tabular}

Tabla 3. Normas de descripción de aplicación global

\begin{tabular}{lll} 
Objeto a describir & $\begin{array}{l}\text { Estándares de } \\
\text { contenido }\end{array}$ & $\begin{array}{l}\text { Estándares de estructura de } \\
\text { datos }\end{array}$ \\
\hline Documentos & ISAD $(\mathrm{G})$ & EAD \\
Agentes & ISAAR $(\mathrm{CPF})$ & EAC \\
& ISDIAH & EAG \\
Funciones & ISDF &.-- \\
\hline
\end{tabular}


Tabla 4. Normas de descripción de aplicación sectorial

\begin{tabular}{lll} 
Objeto a describir & $\begin{array}{l}\text { Estándares de } \\
\text { contenido }\end{array}$ & $\begin{array}{l}\text { Estándares de estructura de } \\
\text { datos }\end{array}$ \\
\hline Documentos & MDM & EMCAU \\
& NOGADA & EDARA \\
& NODAC & VMGC \\
& & e-EMGDE \\
Agentes & ARANOR & e-EMGDE \\
Funciones &.-- & e-EMGDE \\
\hline
\end{tabular}

Con el paso de los años, esta situación derivó en un complejo escenario con múltiples normas para describir en archivos, desarrolladas por órganos de normalización muy diversos para cumplir cada una de ellas con finalidades muy específicas, cuyo cumplimiento, en ocasiones, resultaba incompatible con el de otras.

Esta realidad trajo como principal consecuencia el desencanto con la normalización tal y como se venía asumiendo desde sus primeros años. Se llegó incluso a descartar algunas de las normas de descripción básicas como elementos normativos, y se buscaron alternativas en ámbitos ajenos al mundo de la gestión documental donde, aparentemente, no existía un consenso regulador suficiente y en cuyas opciones no se prestaba especial atención a los principios básicos de la gestión documental.

Era necesario, por tanto, ofrecer una solución eficaz y segura ante esta peligrosa situación de desencanto, afrontando el reto de diseñar un nuevo escenario normativo que resolviera la situación, aglutinara todos los desarrollos existentes ofreciendo un mecanismo de coordinación entre ellos y evitará, en todo caso, convertirse en una norma más dentro de ese panorama superpoblado de reglas de descripción. 


\section{Replanteamiento del proceso: documentos en contexto y nuevas normas}

Para poder comprender mejor cómo obtener una solución eficaz a esta situación, debemos analizar la forma en que se aplican las normas de descripción actuales.

Para ello, si analizamos el proceso de descripción desde una perspectiva secuencial, entendido como un conjunto de actividades encaminadas a representar información sobre los documentos, lo que estamos haciendo es identificar una serie de elementos informativos que están presentes en los documentos y representarlos mediante sus correspondientes metadatos.

Visto así, en realidad se trata de un proceso sencillo y lineal en el que las normas de descripción actuales cumplen un papel regulador de los elementos informativos a describir, ya sea identificando el tipo de información o la estructura a la que esa información debe ajustarse. En función de la norma o normas que deseemos aplicar, los elementos informativos y su estructura serán distintos. Una vez planteado así, el proceso puede ejecutarse tantas veces como sea necesario, generando descripciones ajustadas a esas normas en las que, en última instancia, la selección de información se realiza individualmente en cada descripción.

Pero si analizamos ese mismo proceso, no ya desde una perspectiva basada en las actuaciones a realizar, sino desde la perspectiva del tipo de información que se representa al describir, la percepción del proceso descriptivo puede variar.

Cuando se identifica la información a describir, se puede llegar a una conclusión básica: no toda la información representada en la descripción de un documento corresponde a ese documento, sino también al contexto 
que lo rodea. Hay información que, estando vinculada al documento, desde una perspectiva teórica, en realidad corresponde a otros elementos (por ejemplo, nombres de instituciones, normas que lo regulan, personas implicadas, procedimientos aplicados, etc.). Lo más común es que ese tipo de información no se use de forma exclusiva en una única descripción, sino que puede ser empleada en múltiples descripciones al mismo tiempo. Por ello, puede ser tratada de forma independiente a las descripciones de los documentos, llegando incluso a disponer de repositorios específicos para la gestión de dichas descripciones. Por ejemplo, repositorios de procedimientos donde gestionar las descripciones de actividades, o directorios donde gestionar las descripciones de instituciones o personas implicadas en la gestión de los documentos.

Identificando estos diversos elementos como entidades diferenciadas de las descripciones de los propios documentos, se puede obtener una red de descripciones archivísticas que conecta las descripciones de los documentos, no sólo con relaciones entre ellas mismas, sino también a través de otras múltiples formas de relaciones entre instituciones, funciones, procedimientos, normas, etc.

De esta forma, el panorama donde se gestionan las descripciones se puede concebir como un sistema extensible ad infinitum en el que los documentos reflejan la misma información inicialmente requerida pero resultan accesibles de muchísimas formas no planteadas mediante un proceso descriptivo lineal. Todo ello permite el uso compartido de información, ahorrando costes de tratamiento y haciendo más eficiente la gestión de la información.

Esta nueva perspectiva de la descripción recibe la denominación de descripción de documentos en contexto, en la que ese contexto se configura como la información representada mediante el uso de 
relaciones entre múltiples entidades; de forma que cuantas más relaciones puedan desplegarse, de mejor calidad resultará la información por ser más accesible (Figura 1).

Este planteamiento de la descripción de los documentos en su contexto precisa de una nueva concepción de la descripción, entendiendo que es preciso identificar la forma en que los sistemas de descripción pueden gestionar las entidades a describir (documentos, instituciones, procedimientos, normas, etc.) y las posibles relaciones entre ellas. Esto implica una labor de estandarización del proceso de descripción, no ya en el momento de identificar la información que se va a representar, sino en una etapa anterior, concretamente aquella en la que se establecen los requisitos que debe cumplir el sistema que se va utilizar para describir. Es decir, qué entidades archivísticas se van a poder emplear y qué tipo de relaciones entre ellas pueden configurarse para describirlas.

\section{Documentos en contexto}

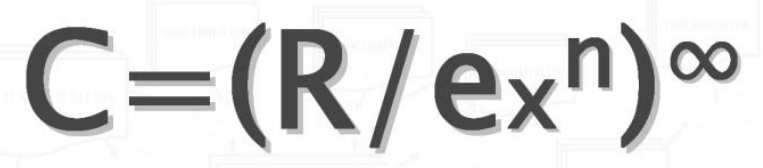

Contexto $=$ Relaciones entre múltiples entidades

Más relaciones $=$ Mejor información

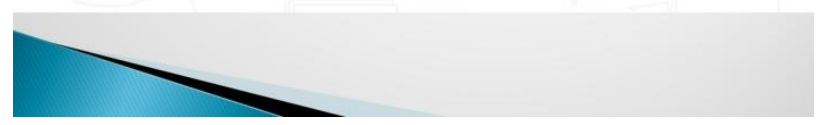

Figura 1: Documentos en contexto 
En este sentido, ninguna de las actuales normas de descripción ofrece una solución para estandarizar esta etapa. Si queremos ofrecer un resultado orientado a cumplir con el objetivo básico de la descripción, que no es otro que hacer accesible y dar a conocer la existencia de documentos representando información, es preciso plantear unas normas nuevas que permitan estandarizar la forma en que se diseñan los sistemas de descripción, con la intención de poder compartir la información que se gestione a través de ellos.

Estas nuevas normas para el diseño de sistemas de descripción deberían resultar de aplicación en cualquier tipo de entorno descriptivo. Por ello, se plantean como un esquema teórico o conceptual que podrá ser implementado de manera flexible y adaptada a las necesidades de cada organización. Además, precisamente por estar concebidas como un modelo conceptual, resultan compatibles con sistemas de descripción analógica tradicional y con sistemas de descripción de documentos digitales.

Para dar respuesta a esta nueva necesidad, ya existen posibles soluciones normativas. La más relevante actualmente es la Norma Española de Descripción Archivística: Modelo Conceptual (NEDA-MC o Modelo Conceptual de Descripción Archivística), cuyo desarrollo comenzó en el año 2007, siendo finalmente aprobado en 2017 por la Comisión de Normas Españolas de Descripción Archivística (CNEDA) como norma para diseñar sistemas de descripción. En NEDA-MC se identifican seis posibles entidades como elementos a describir, así como las posibles relaciones entre dichas entidades. Presta especial atención a las relaciones entre Documentos, Agentes, Funciones y Normas, por considerarse las entidades básicas para definir adecuadamente el contexto documental. 
Pero el contenido regulador del NEDA-MC no se queda limitado a una simple identificación de entidades y relaciones, sino que también ofrece un esquema de los atributos descriptivos, es decir, las propiedades informativas básicas, para describir Documentos, Agentes, Funciones, las relaciones y las propias descripciones que se realicen. Esta relación de atributos permite ejercer como enlace entre los diversos esquemas descriptivos o normas de estructura que, si bien pueden resultar incompatibles de forma directa entre sí, a la hora de analizar la información ofrecida en dichos estándares, son compatibles con el esquema de atributos de la norma española. Esto facilita en última instancia la compatibilidad a través del NEDA-MC de ese conjunto de normas actualmente en vigor, y sobre el cual pendía tanto esa sensación de desencanto como la incompatibilidad (Figura 2).

Además del NEDA-MC, también hay que tener en cuenta la existencia de otro proyecto normativo de ámbito internacional con el mismo objetivo. Se trata del Modelo Conceptual de Descripción Archivística Internacional, conocido como $\mathrm{RiC}-\mathrm{CM}$, por la abreviatura de Records in Contexts: a Conceptual Model for Archival Description, cuyo primer borrador fue difundido en septiembre de 2016. Hoy por hoy se encuentra todavía en fase de análisis de comentarios para poder adoptar formalmente una versión definitiva.

El RiC-CM es el resultado del trabajo realizado entre 2012 y 2016 por el Consejo Internacional de Archivos a través del Grupo de Expertos en Descripción Archivística (ICA/EGAD), y pretende ofrecer una solución al mismo problema planteado anteriormente: la regulación del diseño de sistemas de descripción como paso necesario para estandarizar adecuadamente la descripción archivística. 


\section{Compatibilidad de NEDA-MC}

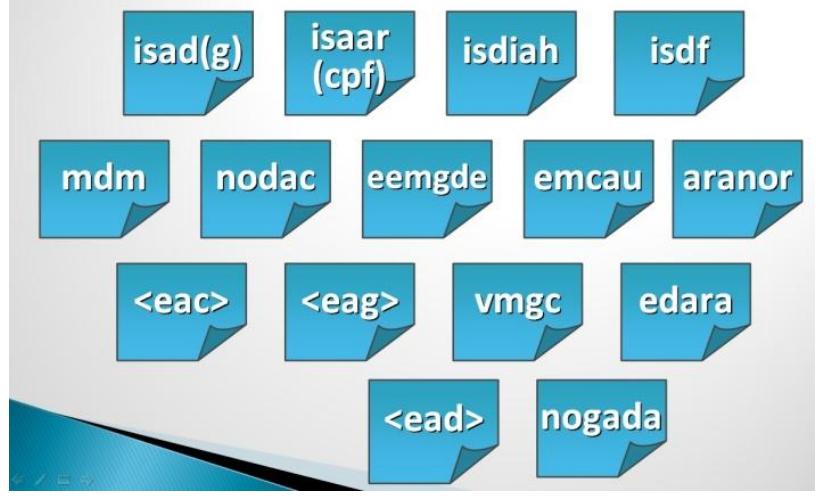

Figura 2: Compatibilidad de NEDA-MC

Si bien es cierto que el NEDA-MC es una norma que ha sido ya aprobada formalmente en 2017 y que el RiC-CM se encuentra todavía en fase de borrador, comparando el contenido de ambas normas puede resultar algo chocante el hecho de que, a pesar de estar planteadas para dar respuesta a una misma necesidad y utilizar un modelado conceptual, el contenido de ambos modelos no sea el mismo. Así, algunas de las diferencias que se pueden identificar a simple vista entre ambos modelos son las siguientes:

- En el NEDA-MC se despliegan 6 entidades frente a las 14 que se plantean en el RiC-CM.

- En el NEDA-MC se identifica unas 40 relaciones entre entidades, frente a las más de 700 del RiC-CM.

- Algunos de los atributos incluidos en el NEDA-MC no parecen coincidir con los que se plantean en el RiC-CM (en cuyo modelo reciben el nombre de properties). 
Esta situación puede inducir a ver inicialmente una incompatibilidad entre ambos modelos, pero si planteamos un estudio comparativo más detallado entre ambas normas, podemos comprobar que no hay tal incompatibilidad.

En primer lugar, hay que tener en cuenta que el RiC-CM se encuentra todavía en fase de borrador, y puede ocurrir que algunas de estas diferencias no resulten tales en la versión definitiva.

En segundo lugar, aunque el NEDA-MC identifica 6 entidades, en algunas de ellas admite la existencia de tipos de entidad, alcanzando un mínimo de 20 posibles tipos, los cuales resultan plenamente compatibles con las entidades identificadas en el RiC-CM (Figura 3).

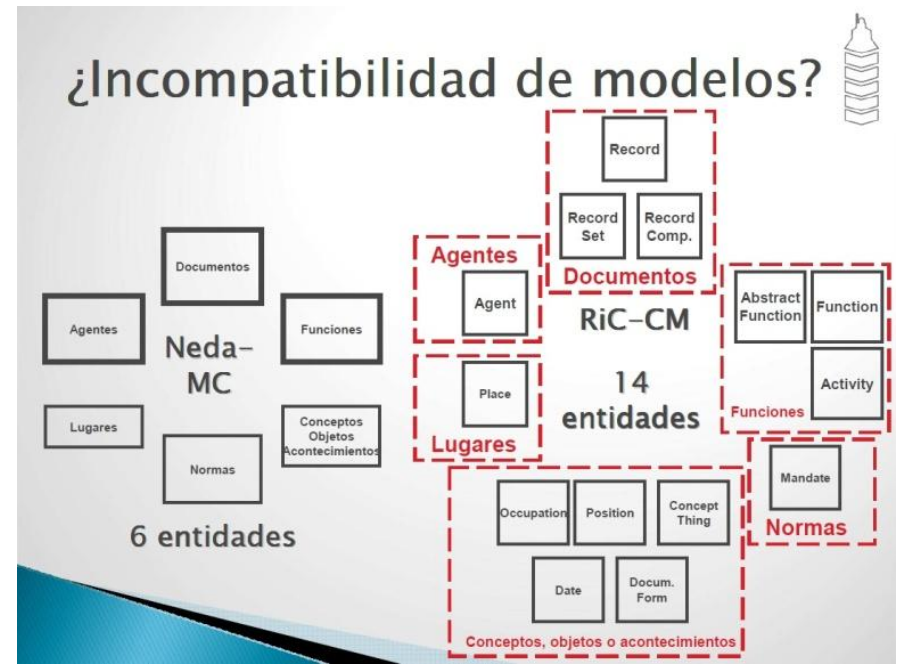

Figura 3: ¿Incompatibilidad de modelos? 
En tercer lugar, el NEDA-MC identifica un número muy limitado de relaciones. Sin embargo, en ningún momento las considera como únicas y exclusivas, sino que admite la posibilidad de ampliar las relaciones entre entidades siempre que se precise, aceptando que las relaciones que quedan identificadas en el NEDA-MC son aquellas que pueden resultar básicas o de uso generalizado.

Por último, los atributos del NEDA-MC son compatibles con las normas internacionales de descripción archivística, así como con las demás normas de descripción actualmente en vigor. Por ello, cuando se adopte formalmente el $\mathrm{RiC}-\mathrm{CM}$ con sus atributos, se podrá plantear su compatibilidad o, si fuera necesario, su posible revisión en una nueva versión.

\section{Conclusiones}

A la vista de que las normas de descripción adoptadas hasta el año 2015 no permitían dar una respuesta adecuada a la nueva necesidad planteada en torno a los requisitos funcionales que deben cumplir los sistemas de descripción, entre los que se incluyen todos aquellos sistemas de gestión orientados a la administración electrónica, la comunidad archivística ha venido tomando cartas en el asunto y, finalmente, gracias a la adopción del NEDA-MC en el ámbito español y a la previsible adopción internacional del RiC-CM, esta carencia se verá solventada.

A partir de ahora, ya existen estándares para diseñar los sistemas donde se gestionan las descripciones archivísticas de documentos, instituciones, personas, funciones y otras muchas entidades de uso. Tan sólo falta que empiecen a aplicarse en el diseño de los futuros sistemas de descripción, o que los sistemas implementados hasta ahora reconduzcan sus 
arquitecturas para cumplir con la finalidad última de la normalización de la descripción: poder compartir la información.

Puesto que la administración viene experimentando un profundo cambio en su propia naturaleza y que, a su vez, dicho cambio conlleva una revisión total del modelo de gestión documental que deriva en una modificación sustancial del escenario descriptivo, cabe concluir que lo más lógico es que las normas de descripción que sirven para regular ese escenario, deben también evolucionar en la misma línea. Es por este motivo que, como queda demostrado a través del NEDA-MC y del RiCCM, ya se está trabajando en unas nuevas normas que se adapten a esta nueva administración, a esos nuevos modelos de gestión documental y a los nuevos escenarios descriptivos.

\section{Bibliografía}

Comisión de Normas Españolas de Descripción Archivística (2017). NEDA-MC: Modelo conceptual de descripción archivística: Entidades, relaciones y atributos. Recuperado de <http://www.mecd.gob.es/cultura/areas/archivos $/ \mathrm{mc} / \mathrm{cneda} /$ documentacion/normas/neda-mc.html $>$.

International Council on Archives. Experts Group on Archival Description. (2016). RiC-CM. Records in Contexts: a conceptual model for archival description. Consultation draft v0.1. Recuperado de <http://www.ica. org/sites/default/files/RiC-CM-0.1.pdf>.

Requejo Zalama, J. (2015). Auge y caída de la descripción multinivel: el nuevo entorno multi-dimensional de la descripción archivística. En Actas de las VIII Jornadas Archivando, Valor, Sociedad y Archivos (pp. 23-39). Recuperado de $\langle$ https://dialnet.unirioja.es/congreso/edicion/8097>.

Requejo Zalama, J. (2016). NEDA: modelos de descripción y modelos de presentación. Tábula, 19, 299-309. Recuperado de <http://publicacio nes.acal.es/index.php/tabula/issue/view/57>. 

ARPAD: el proyecto de archivo electrónico de Galicia

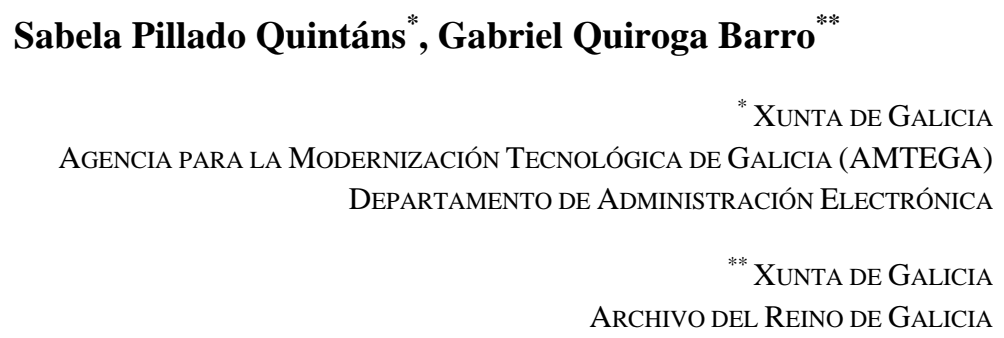

\section{Resumen}

ARPAD (Archivo y Patrimonio Documental) es un proyecto desarrollado en el marco de la tercera convocatoria del Programa de Cooperación Transfronteriza España-Portugal (POCTEP) 2007-2013, que ha permitido crear el Archivo Digital Integrado de Galicia (o Archivo Electrónico de Galicia) y avanzar en la conservación y difusión del patrimonio documental en soporte tradicional custodiado en los archivos de la Comunidad Autónoma, entre otros objetivos.

Impulsado por la Agencia para la Modernización Tecnológica de Galicia (AMTEGA), como beneficiario principal, ha contado con otros socios en la Xunta de Galicia (entre ellos la Secretaría Xeral de Cultura de la Consellería de Cultura, Educación y Ordenación Universitaria), el Ayuntamiento de Tui y la Diputación Provincial de Pontevedra, por parte española, y la Comunidade Intermunicipal do Minho-Lima (CIM Alto Minho), por la portuguesa.

El Archivo Digital Integrado de Galicia se puede definir tanto como una estructura tecnológica como una estructura organizativa de procedimientos y responsabilidades. En cuanto a lo primero, permite la gestión y el archivo de documentos electrónicos producidos por el sector 
público autonómico y de copias digitalizadas de los documentos del patrimonio documental que se custodian en los archivos gallegos. En cuanto a lo segundo, permite el funcionamiento de esas infraestructuras y de cada uno de sus elementos de acuerdo con la legislación vigente y las normas y buenas prácticas internacionales. Son precisamente esas normas las que nos servirán de soporte didáctico en nuestra exposición.

Palabras clave: Archivo Digital Integrado de Galicia; Archivo electrónico único; Gestión documental electrónica; Patrimonio documental digital

Cita recomendada: Pillado Quintáns, S., y Quiroga Barro, G. (2018). ARPAD: el proyecto de archivo electrónico de Galicia. En El archivo electrónico en la administración digital: 23 Jornadas de Archivos Universitarios, 21-23 de junio de 2017, A Coruña (pp. 43-59).

DOI capítulo: https://doi.org/10.17979/spudc.9788497496803.043 DOI libro: https://doi.org/10.17979/spudc.9788497496803

\section{Visión del Archivo Digital Integrado}

Desde un punto de vista tecnológico, el modelo de ARPAD integra dos infraestructuras diferentes: el denominado Archivo Electrónico Administrativo y el Archivo Electrónico del Patrimonio Documental. El núcleo del primero es un repositorio Alfresco sobre el que se ha construido una capa de servicios, que permite la integración de diferentes aplicaciones que hacen posible la gestión documental y el funcionamiento del archivo electrónico: desde el registro electrónico o las aplicaciones de gestión/tramitación propiamente dichas, el portafirmas, la aplicación de notificaciones electrónicas, el generador de índices, el generador de Código Seguro de Verificación (CSV), el gestor de identidades, la 
aplicación de digitalización garantizada hasta dos aplicaciones clave: el Inventario de Información Administrativa y la Aplicación de Captura y Consulta.

El Archivo Electrónico del Patrimonio Documental se basa en un repositorio diseñado para desarrollar las funcionalidades de preservación de objetos digitales que propone el modelo Open Archival Information System (OAIS). De forma separada, pero en relación con este repositorio, se ha diseñado una aplicación de gestión de descripciones archivísticas, y otra para la recolección y difusión de los metadatos de los objetos digitales transferidos desde el Archivo Electrónico Administrativo o creados a partir de la digitalización del patrimonio documental analógico (Figura 1).

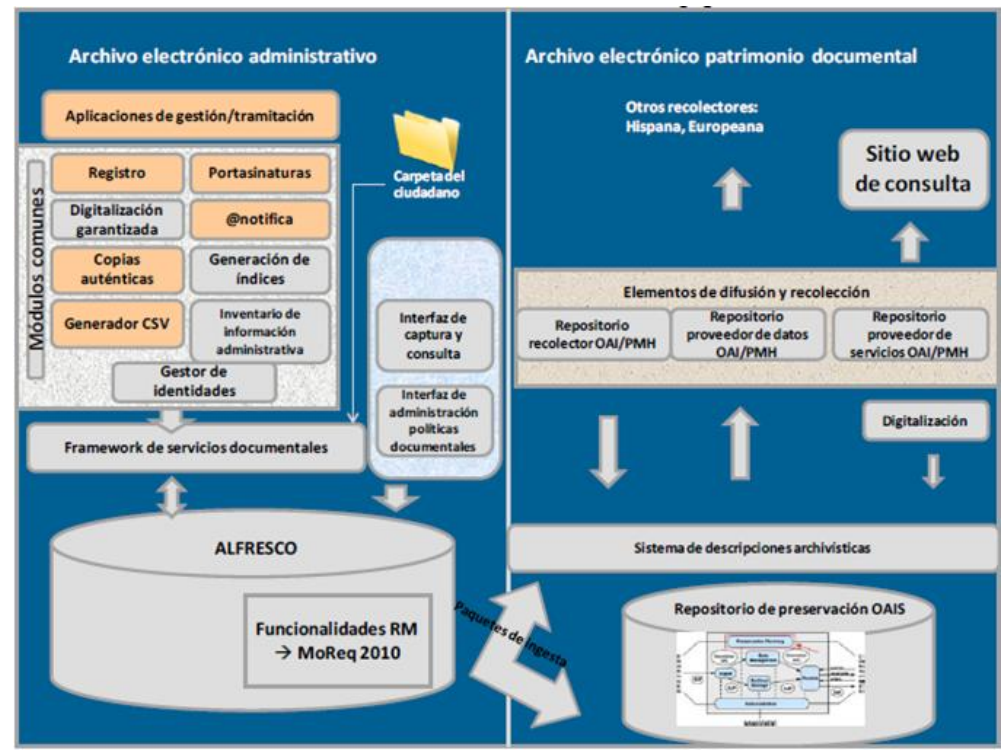

Figura 1: Visión del Archivo Digital Integrado de Galicia 
En las páginas que siguen nos proponemos desarrollar esta breve visión de forma más detallada. Nos apoyaremos, con finalidad meramente didáctica, en el guion de la renovada Norma UNE ISO 15489-1 (Asociación Española de Normalización y Certificación [AENOR], 2016).

\section{Políticas y responsabilidades}

Por Resolución conjunta del 15 de diciembre de 2014, de la AMTEGA y de la Secretaría Xeral de Cultura de la Xunta de Galicia (DOG núm. 4 de 8 de enero de 2015), se aprobó el Marco de Referencia del Archivo Digital Integrado de Galicia (MRA). Según esta resolución, el MRA actuará "como contexto para el desarrollo de la política de gestión de documentos electrónicos de la Xunta de Galicia, según los fines establecidos en el Esquema Nacional de Interoperabilidad (ENI) y en la Norma Técnica de Interoperabilidad de Política de Gestión de Documentos Electrónicos" (apartado tercero), y "es el documento que sintetiza el modelo de gestión de los documentos electrónicos sobre el que se desarrolla el Archivo Digital Integrado de Galicia” (preámbulo).

No es por tanto la política de gestión de documentos electrónicos de la Xunta de Galicia, pero es un documento fundamental que diseña ya todos los elementos básicos sobre los que habrá de desarrollarse esa política. En este sentido, el MRA:

1) Aborda de forma sistemática la legislación, la normativa técnica y buenas prácticas de gestión documental electrónica.

2) Describe los tres escenarios en que se desarrollará la gestión documental en la Administración gallega.

3) Enumera los denominados "clientes" ARPAD, es decir, las entidades o personas que son o pueden ser sus beneficiarias. 
4) Expone el modelo de gestión documental y sus principios.

5) Enumera y describe los procesos de gestión documental en el modelo de gestión documental aplicado al sector público autonómico.

6) Describe los modelos organizativos (y define las responsabilidades de los diferentes agentes participantes en la planificación, implantación, desarrollo y mantenimiento del Archivo Digital Integrado) y tecnológico.

7) Expone la normativa, la documentación y los instrumentos del modelo.

Completan el documento un glosario y dos anexos ("Disposiciones legislativas y normativa aplicada" y "Relación de normativa y documentación a desarrollar"). Su contenido completo está accesible de forma permanente en la intranet de la Xunta de Galicia.

\section{Instrumentos de gestión de documentos}

Destacaremos dos instrumentos fundamentales: el esquema de metadatos ARPAD y el Cuadro de clasificación funcional del Archivo de Galicia.

\subsection{Esquema de metadatos ARPAD}

Basada en la primera versión del e-EMGDE (Esquema de Metadatos para la Gestión del Documento Electrónico, 2012), se ha propuesto un modelo a desarrollar desde una aproximación mono-entidad (documento) de acuerdo con el esquema estatal y la Norma UNE ISO 23081 de metadatos para la gestión de documentos (AENOR, 2008). Comprende 63 elementos y subelementos. Incluye metadatos que no figuraban en esa primera versión del e-EMGDE, luego parcialmente recogidos en eEMGDE 2.0 (2016), como por ejemplo los referidos a Versión NTI (Norma Técnica de Interoperabilidad) o Asiento registral (Tabla 1). 
Tabla 1: Metadatos aplicables al nivel de serie documental de acuerdo con el Esquema de Metadatos ARPAD

\begin{tabular}{lll} 
Nombre Formal & Etiqueta & $\begin{array}{l}\text { Equivalencia e-EMGDE (Versión 10- } \\
\text { 02-2012) }\end{array}$ \\
\hline ARPAD.SERIE.CATEGORIA & Categoría & eEMGDE1 \\
ARPAD.SERIE.IDENTIFICADOR & Código & eEMGDE2.1 \\
ARPAD.SERIE.NOMBRE & Nombre & eEMGDE3.1 \\
ARPAD.SERIE.DESCRIPCION & Descripción & eEMGDE5 \\
ARPAD.SERIE.IDENTIFICADOR_PRODUCTOR & Código del órgano productor & eEMGDE2.1 \\
ARPAD.SERIE.NOMBRE_PRODUCTOR & Nombre del órgano productor & eEMGDE3.1 \\
ARPAD.SERIE.IDENTIFICADOR_PROCEDIMIENTO & Procedimiento & eEMGDE2.1 \\
ARPAD.SERIE.NOMBRE_PROCEDIMIENTO & Nombre del Procedimiento & eEMGDE3.1 \\
ARPAD.SERIE.CODIGO_CLASIFICACION & Código clasificación & eEMGDE22.1 \\
ARPAD.SERIE.NOMBRE_CLASIFICACION & Nombre clasificación & eEMGDE22.2 \\
ARPAD.SERIE.TIPO_DICTAMEN & Tipo de dictamen & eEMGDE13.2.1 \\
ARPAD.SERIE.ACCION_DICTAMINADA & Acción dictaminada & eEMGDE13.2.2 \\
ARPAD.SERIE.TIPO_ACCESO & Tipo de acceso & eEMGDE9.2 \\
ARPAD.SERIE.LOPD & Valoración LOPD & eEMGDE8.4 \\
ARPAD.SERIE.ENS & Valoración ENS & eEMGDE8.5 \\
ARPAD.SERIE.SERIE & Serie relacionada & eEMGDE6.1 \\
\hline
\end{tabular}




\subsection{Cuadro de clasificación funcional del Archivo de Galicia}

El cuadro que se ha implementado en el Archivo Electrónico de Galicia es el actualmente vigente en el Archivo de Galicia para la gestión de los documentos en papel de la Xunta de Galicia, basado en el Estudio orgánico funcional de la Administración autonómica publicado en 2010 (Quiroga, 2010).

Identifica y recopila agentes, normas y funciones de la Administración Autonómica desde su creación. Propone un cuadro de clasificación basado en 18 grandes funciones o competencias de la Administración Autonómica. El segundo y los siguientes niveles de clasificación se desarrollan de acuerdo con una estructura uniforme basada en la propuesta de Mateo Páez (2002).

Como se señala en MRA, el cuadro de clasificación es un instrumento vivo que debe ser desarrollado en el marco del proceso del análisis documental. En este contexto, se han detectado ya problemas intrínsecos como, por ejemplo, series comunes dependientes de dos o más funciones o series transversales dependientes de funciones específicas, entre otros. Otros problemas son propios del entorno electrónico, en el que el cuadro de clasificación, además de vincular los documentos a su contexto, se convierte en un instrumento para la agrupación de los que comparten calendarios de conservación y reglas de acceso (Norma 15489, 2016, p. 22).

Así, existe en la actualidad una nueva propuesta que parte del análisis realizado hasta el momento y de las experiencias de las comunidades autónomas de Andalucía (Páez, 2004) y Canarias (Gobierno de Canarias, s.f.). En esta propuesta, se reduce el número de secciones y se pone el foco en la esencia funcional para superar los inconvenientes enunciados (Tabla 2). 
Tabla 2: Propuesta de Cuadro de clasificación funcional del Archivo Digital Integrado de Galicia
1) Alta dirección y gobierno
2) Administraciones públicas y organización administrativa
3) Política económica, hacienda y gestión de recursos económicos
4) Ordenación y regulación
5) Fomento
6) Prestación de servicios públicos
7) Seguimento y valoración
8) Control, inspección y sanción

\section{Identificación y valoración}

En el modelo diseñado en el MRA, el análisis documental constituye un proceso fundamental de la gestión documental que se aplicará de manera continua, al ritmo de la habilitación en el sistema de procedimientos electrónicos y de implementación de las aplicaciones de gestión documental electrónica (Xunta de Galicia, 2014).

El análisis documental identifica las series documentales y los procedimientos con los que se relacionan, y sus resultados comprenden:

1) el establecimiento de las relaciones entre procedimientos y series en el cuadro de clasificación;

2) la identificación de las relaciones entre las unidades productoras, las series y los procedimientos a lo largo del tiempo;

3) la determinación de los documentos que deben incluirse en los expedientes y sus tipos documentales;

4) el flujo documental y las características de los documentos; 
5) la identificación de las aplicaciones relacionadas con la creación y recepción de documentos;

6) la determinación de necesidades de metadatos específicos para cada serie documental en el marco del esquema ARPAD y, en su caso, los requisitos específicos de ubicación, agrupación y clasificación de los documentos en el repositorio;

7) el establecimiento de las reglas y categorías de acceso una vez finalizado el procedimiento; $y$

8) el informe de valoración sobre los plazos de transferencia y conservación que se eleva al Consello de Avaliación Documental (Xunta de Galicia, 2014).

El análisis para cada serie documental debe realizarse antes de comenzar a capturar documentos y expedientes electrónicos en el archivo electrónico, salvo en el caso del informe de valoración, que puede realizarse a posteriori (Xunta de Galicia, 2014, p. 20).

El Inventario de Información Administrativa (IIA) es la aplicación que facilita la realización del análisis documental y el mantenimiento del cuadro de clasificación, entre otros procesos; en sincronía con el repositorio documental del Archivo Electrónico Administrativo (e, indirectamente, con las aplicaciones de gestión vinculadas a éste), hace efectivos los diversos procesos de gestión documental definidos en el modelo.

En este contexto, cobra una importancia vital la aplicación REDUCE, que se utiliza para habilitar todos los procedimientos electrónicos. De acuerdo con la Orden de 12 de enero por la que se regula la habilitación de procedimientos administrativos y servicios en la Administración general y en el sector público autonómico de Galicia (DOG núm. 10 de 2012), los 
procedimientos y servicios establecidos por una disposición de carácter general deben ser habilitados y validados de forma conjunta por la Dirección General de Evaluación y Reforma Administrativa y la Agencia para la Modernización Tecnológica de Galicia a través de la aplicación REDUCE. En un esquema ideal de funcionamiento, el análisis documental debería formar parte de este proceso de habilitación de procedimientos (Xunta de Galicia, 2014).

En la actualidad, ya existen 40 procedimientos electrónicos, previamente habilitados y que son gestionados desde las aplicaciones, cuyos expedientes se producen, capturan y gestionan de forma íntegra en el Archivo Electrónico Administrativo. Otros 40, aproximadamente, se han analizado ya y su información se halla cargada en el Inventario de Información Administrativa, por lo que en breve las aplicaciones que los gestionen podrán efectuar su creación, captura y almacenamiento en el sistema.

\section{Implantación del Archivo Electrónico Administrativo de la Xunta de Galicia en el marco del proyecto ARPAD}

El Marco de Referencia del Archivo Electrónico Integrado, partiendo de una visión integradora, da cobertura a tres escenarios en los que la gestión de documentos electrónicos tiene distintos objetivos y condicionantes. Los tres comparten los principios del modelo de gestión documental, pero pueden presentar diferencias en la forma de plantear la implantación de los procesos documentales y la tecnología usada como soporte. 
Los tres escenarios contemplados son:

- Escenario 1: gestión documental soporte de la actuación administrativa antes, durante y después de la finalización del trámite.

- Escenario 2: digitalización sustitutiva de actuaciones administrativas realizadas en papel.

- Escenario 3: digitalización del patrimonio documental.

La implantación del Archivo Electrónico Administrativo de la Xunta de Galicia se desarrolla en los escenarios 1 y 2 definidos en el modelo, y hasta el momento se ha avanzado fundamentalmente en el escenario 1.

Para el escenario 1, que trata de la gestión documental soporte de la actuación administrativa, el Marco de Referencia tiene en cuenta que las administraciones públicas se encuentran en un momento de profunda trasformación hacia la administración electrónica. Esta supone la gestión de documentos electrónicos que progresivamente irán sustituyendo a los documentos en papel. Este escenario contempla, por lo tanto, toda la gestión de los documentos electrónicos que se producen y reciben en el marco de la actuación administrativa. Considera todos los estados del documento desde que se crea hasta que se determina su destrucción o conservación permanente.

El objetivo principal de la gestión documental en este escenario es la eficacia y eficiencia de los procedimientos administrativos; pero sin perder de vista la necesidad de gestionar los documentos de manera que, finalizados los trámites, estos sean consultables por quien los necesite y se les puedan aplicar los plazos de conservación correspondientes. 
La gestión documental en este escenario debe integrarse con los procesos de trabajo y, por lo tanto, con las aplicaciones de gestión y tramitación existentes, y además con los restantes componentes tecnológicos transversales, como son: el sistema único de registro, el Inventario de Información Administrativa, el sistema de notificación electrónica y la plataforma de firma electrónica.

Para la puesta en marcha del Archivo Electrónico Administrativo de la Xunta de Galicia se adoptaron una serie de decisiones estratégicas, orientadas a garantizar un proyecto viable que permitiera obtener resultados con los medios disponibles en un corto plazo de tiempo, adaptándose a los condicionantes de la financiación del proyecto.

Una de las premisas consideradas antes de abordar el proyecto fue tener en cuenta la situación de partida en la implantación de la tramitación electrónica en los procedimientos administrativos, tanto desde un punto de vista organizativo como tecnológico.

Así, organizativamente se optó por una visión integrada, en la que la incorporación de los documentos generados en la gestión de procedimientos administrativos en el archivo electrónico administrativo es un aspecto más en el proceso de implantación de la tramitación electrónica de procedimientos, que ya estaba implantado y maduro en la organización.

En el ámbito tecnológico se tuvo en cuenta el estado de las herramientas y aplicaciones que se utilizaban en la tramitación electrónica de procedimientos, centrando inicialmente los esfuerzos en incorporar al archivo electrónico administrativo aquellos procedimientos que ya tenían una herramienta de tramitación o que estaban en proceso de implantarla. Se optó, además, por incorporar en las herramientas de tramitación las 
utilidades necesarias para la gestión documental, abstrayendo a los usuarios de las complejidades técnicas tanto informáticas como archivísticas.

La Xunta de Galicia dispone de un conjunto de servicios electrónicos que deben tenerse en cuenta en el proceso de implantación del Archivo Electrónico Administrativo, especialmente la sede electrónica, el sistema único de registro, la plataforma corporativa de firma y la plataforma de intermediación de datos.

La sede electrónica se puso en marcha en el año 2011 y ofrece a los ciudadanos y empresas la posibilidad de realizar más de mil trámites electrónicos distintos. En 2016 se recibieron más de 89000 solicitudes, escritos o comunicaciones a través de la sede electrónica.

El Sistema Único de Registro de la Xunta de Galicia está ya digitalizando parte de los documentos que los ciudadanos presentan en papel y, en particular, aquellos que se dirigen a otras administraciones públicas integradas con el Sistema de Interconexión de Registros del Ministerio de Hacienda y Función Pública, lo que permite el intercambio electrónico de la información de los asientos registrales y de su documentación asociada.

En el ámbito de la gestión interna, la plataforma corporativa de firma permite firmar documentos electrónicos tanto a los empleados públicos como en las actuaciones administrativas automatizadas. En 2016 se firmaron más de un millón de documentos en esta plataforma.

En todos estos sistemas se está produciendo un crecimiento elevado en el volumen de documentos gestionados y se prevé que siga aumentando debido a la entrada en vigor de las distintas previsiones de la normativa 
de procedimiento administrativo y de régimen jurídico de las administraciones públicas. Estos documentos formarán parte del Archivo Electrónico Administrativo, que debe continuar desarrollándose para dar cobertura a estas necesidades.

El Archivo Electrónico Administrativo de la Xunta de Galicia almacena actualmente más de 800000 documentos y 50000 expedientes asociados a más de cuarenta series documentales, y debe continuar evolucionando para dar cabida a las nuevas necesidades y demandas de gestión documental. Así, es necesario continuar las distintas líneas de trabajo del proyecto, que se pueden estructurar en cuatro ejes:

- Definición y evolución del modelo, publicando formalmente la política de gestión de documentos electrónicos de la Xunta de Galicia que integre los componentes y documentos ya publicados hasta el momento: marco de referencia, modelo de metadatos, catálogo de tipos documentales, cuadro de clasificación funcional y modelo de integración de aplicaciones.

- Componentes tecnológicos, dotando a las herramientas disponibles de nuevas funcionalidades y de mejoras en el rendimiento que faciliten la incorporación ágil de procedimientos y series documentales. También es necesario avanzar en la interoperabilidad de herramientas, permitiendo el intercambio electrónico de expedientes entre administraciones públicas.

- Procesos documentales, incorporando y consolidando los procesos documentales asociados, haciendo que todas las unidades implicadas conozcan cuáles son sus tareas y responsabilidades en este ámbito.

- Integración de procedimientos y herramientas: el Archivo Electrónico Administrativo actualmente integra la sede electrónica, el Sistema Único de Registro, el Registro Único Empresarial y el 
sistema corporativo de tramitación, en el que se irán incorporando nuevos procedimientos. Es necesario analizar y abordar la integración de otros sistemas de tramitación, nuevos o existentes, a lo largo de los próximos meses, con el objetivo de alcanzar una integración completa en 2018.

\section{Conclusiones}

El proyecto ARPAD ha proporcionado un impulso decisivo al proceso de implantación de la gestión documental electrónica en la administración de Galicia. Proceso en el que la creación y mantenimiento de un archivo digital integrado o archivo electrónico único es un factor esencial, de acuerdo con lo establecido en la legislación de procedimiento administrativo y organización administrativa, y en la legislación y normativa técnica de interoperabilidad y seguridad.

ARPAD ofrece ya resultados tangibles de tramitación y archivo íntegramente electrónicos de procedimientos y expedientes, de acuerdo con la legislación vigente y las buenas prácticas internacionales, si bien queda mucho trabajo por hacer para garantizar su sostenibilidad.

Al integrar también la gestión del patrimonio documental analógico digitalizado en el proyecto, ARPAD se configura como un modelo singular que, en última instancia, contribuye a subrayar la unidad y continuidad de ese patrimonio y su origen en la actividad de las instituciones administrativas del pasado, del presente y del futuro.

El modelo de ARPAD ha puesto también de manifiesto que el desarrollo de la administración y el archivo electrónicos requiere de un gran esfuerzo, no solamente técnico, sino también organizativo. Es necesario 
un alto grado de colaboración entre diferentes administraciones (y órganos administrativos en el seno de cada una de ellas), entre los sectores público y privado, y entre diferentes profesionales y disciplinas (gestión documental y archivo, y tecnologías de la información y la comunicación).

Por otra parte, este gigantesco esfuerzo tiene la virtud de constituir en la práctica un potente factor normalizador y unificador de la gestión administrativa a través de la gestión documental electrónica.

\section{Bibliografía}

Asociación Española de Normalización y Certificación. (2008). UNE-ISO 23081-1:2008 Procesos de gestión de documentos. Metadatos para la gestión de documentos. Parte 1: Principios. Recuperado de 〈http://www.aenor.es〉.

Asociación Española de Normalización y Certificación. (2011). UNE-ISO 23081-2:2011 Procesos de gestión de documentos. Metadatos para la gestión de documentos. Parte 2: Elementos de implementación y conceptuales. Recuperado de <http://www.aenor.es>.

Asociación Española de Normalización y Certificación. (2016). UNE-ISO 15489-1:2016 Gestión de documentos. Parte 1: Conceptos y principios. Recuperado de <http://www.aenor.es>.

Dirección General de Modernización Administrativa, Procedimientos e Impulso de la Administración Electrónica. (2012). Esquema de Metadatos para la Gestión del Documento Electrónico (e-EMGDE). Documentación complementaria a la Norma Técnica de Política de gestión de documentos electrónicos. Madrid: Ministerio de Hacienda y Administraciones Públicas.

Dirección de Tecnologías de la Información y las Comunicaciones. (2016). Esquema de Metadatos para la Gestión del Documento Electrónico (eEMGDE) versión 2.0: documentación complementaria a la Norma Técnica 
de Política de gestión de documentos electrónicos. Recuperado de $<\mathrm{http} / / /$ administracionelectronica.gob.es>.

Gobierno de Canarias (s.f.). Cuadro de clasificación funcional. Recuperado de <http://www.gobcan.es/cpj/dgmcs/temas/archivos/cuadroclasificacionfuncion al.html $>$

Páez García, M. (2002). Cuadro de clasificación funcional para fondos de archivos del subsistema autonómico andaluz: el fondo de la Consejería de Agricultura y Pesca. Sevilla: Junta de Andalucía, Consejería de Agricultura y Pesca.

Páez García, M. (2004). El cuadro de clasificación integrado: normalización de la clasificación archivística, $P H, \quad 47$, 84-95. Recuperado de <http://www.iaph.es/revistaph/index.php/revistaph/article/view/1691>.

Quiroga Barro, G. (dir.) (2010). Estudio orgánico y funcional de la Xunta de Galicia: proposta dun cadro de clasificación. Santiago de Compostela: Xunta de Galicia. Recuperado de <http://arquivosdegalicia.xunta.gal/ export/sites/default/arquivo-de-galicia/resources/downloads/estudio-orgxnico -funcional-xunta-galicia.pdf $>$.

Xunta de Galicia (2014). Archivo Digital Integrado de Galicia: Marco de Referencia. Santiago de Compostela: Xunta de Galicia. 



\section{Políticas e práticas de gestão de documentos eletrónicos na Administração: o que está mudando em Portugal ${ }^{5}$}

\section{Pedro Penteado}

DireÇÃo-Geral do LiVRO, DOS ARQuivos E DAS BiblioteCAS

DireÇÃo DE SERVIÇOS DE ARQUIVÍSTICA E NORMALIZAÇÃo

\section{Resumen}

A comunicação começa por apresentar alguns elementos para a compreensão dos novos contextos para a gestão da informação arquivística na Administração eletrónica. De seguida fornece a perspetiva do organismo de coordenação da política arquivística portuguesa - a Direção-Geral do Livro, dos Arquivos e das Bibliotecas (doravante designado pela sigla DGLAB), sobre as boas práticas de gestão da informação nas entidades da Administração Pública. Nesse sentido, especifica a aposta da DGLAB na interoperabilidade semântica através de instrumentos e produtos específicos como o esquema Metainformação para a Interoperabilidade (MIP), a Macroestrutura Funcional (MEF), a Lista Consolidada de informação relativa a processos de negócio da Administração (LC), com vista à sua classificação e avaliação. Apresenta ainda a proposta da DGLAB para o uso de ferramentas transversais para a

5 A comunicação apresentada, em castelhano, nas XXIII Jornadas de Archivos Universitarios, intitulava-se "Políticas y prácticas de gestión de documentos electrónicos en la Administración: Lo que está cambiando en Portugal". 
classificação e avaliação da informação pública, como as que resultam do Projeto de Avaliação Suprainstitucional da Informação Arquivística (ASIA). Nesse sentido, aprofunda a visão da DGLAB sobre a utilização destes instrumentos nos contextos organizacionais e pluriorganizacionais (por exemplo, nas instituições de Ensino Superior), com vista à elaboração e aplicação de planos de classificação e tabelas de seleção. Especifica também a procura de soluções para o problema da preservação da informação digital, quer a que é produzida no contexto arquivístico da Administração, quer em outras comunidades de prática, através do desenvolvimento do projeto "Continuidade digital". Por último, especifica a política de gestão de documentos eletrónicos existente no país, identificando as suas fragilidades e o que está a ser desenvolvido para as ultrapassar.

Palabras clave: Administração Pública; Gestão de documentos eletrónicos; Interoperabilidade semântica; Política de informação; Portugal.

Cita recomendada: Penteado, P. (2018). Políticas e práticas de gestão de documentos eletrónicos na Administração: o que está mudando em Portugal. En El archivo electrónico en la administración digital: 23 Jornadas de Archivos Universitarios, 21-23 de junio de 2017, A Coruña (pp. 61-74).

DOI capítulo: https://doi.org/10.17979/spudc.9788497496803.061 DOI libro: https://doi.org/10.17979/spudc.9788497496803 


\section{Administração eletrónica: um novo contexto para a gestão da informação arquivística}

Nos últimos quinze anos têm-se acentuado a Administração eletrónica enquanto forma de impulsionar a comunicação entre os vários níveis de Administração Pública (AP) e os diferentes poderes públicos, bem como meio para conseguir oferecer aos cidadãos e às empresas melhores serviços, com mais qualidade, através da melhoria dos processos de trabalho e o uso das tecnologias da informação e comunicação (veja-se, por exemplo, Martínez Usero, 2007). Deste modo, a execução de políticas públicas pela Administração tem-se pautado pelo desenvolvimento de processos de trabalho cada vez mais otimizados e pelo recurso crescente a sistemas de informação integrados e plataformas informáticas que visam favorecer a gestão e a partilha de informação. $\mathrm{O}$ recurso a estas soluções tecnológicas é crítico, principalmente quando estas suportam processos transversais, em grande parte desmaterializados, que atravessam diferentes Administrações e organizações públicas que trabalham em rede na gestão supraorganizacional dos problemas ou casos colocados pelos cidadãos, obrigando ao uso de soluções de interoperabilidade e de reutilização dos dados e informação existentes nos repositórios da Administração, conforme as propostas de vários documentos de política europeia ${ }^{6}$. Neste sentido, a gestão pública obriga a requisitos cada vez mais exigentes no tratamento, preservação e exploração da informação arquivística eletrónica necessária, que se tem de manter utilizável, autêntica e confiável a longo prazo. Por outro lado, estes critérios devem ser definidos e implementados o mais cedo possível

\footnotetext{
${ }^{6}$ Veja-se, por exemplo, o "Plano de ação europeu (2016-2020) para a administração pública em linha. Acelerar a transformação digital da administração pública" COM(2016) 179 final ou a recente versão do "Quadro Europeu de Interoperabilidade - Estratégia de execução", com a publicação da $\operatorname{COM}(2017) 134$ final, ambas Comunicações da Comissão ao Parlamento Europeu, ao Conselho, ao Comité Económico e Social e ao Comité das Regiões.
} 
nas organizações, para o que estas devem ultrapassar as suas limitações estruturais e seguir boas práticas internacionais.

\section{Boas práticas de gestão da informação arquivística}

A gestão da informação arquivística ou gestão de documentos de arquivo, incluindo os de caráter eletrónico, depara, no caso da Administração Pública portuguesa, com obstáculos estruturais para uma rápida e eficaz implementação da mudança exigida pela Administração eletrónica. Alguns destes obstáculos foram identificados nos sucessivos diagnósticos que a DGLAB tem promovido sobre o tema (Penteado, 2015). De entre eles, salientamos: a) na maior parte das entidades, a ausência de formalização de políticas e responsabilidades sobre o respetivo sistema de arquivo; b) a escassa dotação de recursos humanos afetos aos sistemas de arquivo; e c) a não utilização de instrumentos para a gestão de documentos de arquivo, como planos de classificação e tabelas de seleção e planos de preservação digital na maior parte das entidades, favorecendo a acumulação documental.

\subsection{A aposta na interoperabilidade semântica}

Para fazer face aos problemas identificados, a DGLAB tem produzido e promovido um conjunto de normas, orientações e boas práticas de gestão de documentos. Entre elas figura, em primeiro lugar, as que visam promover a Administração eletrónica e a interoperabilidade semântica, em particular, e a construção de instrumentos que permitam o registo e a classificação funcional transversal. Merecem destaque: 
1) o esquema Metainformação para a Interoperabilidade (MIP) com um conjunto de 17 elementos de metainformação descritiva, alguns deles obrigatórios, para registo dos recursos/documentos eletrónicos, baseado em referenciais internacionais (exemplo: ISO 23081, Dublin Core, Moreq, etc). Entre os elementos obrigatórios consta a classificação;

2) a Macroestrutura Funcional (MEF) - representação conceptual de funções e subfunções desempenhadas por organizações do setor público, utilizada para atribuição de classes de $1 .^{\circ}$ e $2 .^{\circ}$ nível a documentos de arquivo.

A DGLAB viria a desenvolver posteriormente, num contexto colaborativo, o projeto de "Harmonização de classes de $3 .^{\circ}$ nível em planos de classificação conformes à MEF", integrando numa Lista Consolidada a informação relativa a processos de negócio da Administração. Para não desenvolver excessivamente o esquema classificativo, utilizou o conceito de mapa conceptual, que entre outros aspetos explicita e torna transparente, para cada classe, todos os critérios e raciocínios lógicos intermédios (entre os 2. ${ }^{\circ} \mathrm{s}$ e $3 .^{\circ} \mathrm{s}$ níveis) que conduziram às propostas apresentadas. Para garantir a normalização no uso deste referencial nos planos de classificação das entidades da AP, a DGLAB passou ter a responsabilidade de aprovar e publicitar a referida Lista Consolidada.

Para promover o MIP e a MEF, bem como para desenvolver documentos técnicos que aprofundem os níveis de interoperabilidade semântica alcançados, a DGLAB coordena o Programa de Administração Eletrónica e Interoperablidade Semântica (PAEIS), de adesão voluntária ${ }^{7}$.

\footnotetext{
${ }^{7}$ Veja-se informação complementar, sobre o PAEIS e os referenciais ou instrumentos citados e os seus pressupostos técnicos e metodológicos, em <http://arquivos.dglab.gov.pt /programas-e-projectos/modernizacao-administrativa/macroestrutura-funcional-mef $>$.
} 
2.2. O Projeto de Avaliação Suprainstitucional da Informação Arquivística (ASIA) e dinâmicas da sua implementação

Numa fase posterior, a partir de 2015, a DGLAB procurou, com a colaboração de centenas de entidades, avaliar a informação estruturada de acordo com a Lista Consolidada, procedendo aos ajustamentos necessários desta. Para o efeito, avançou com o Projeto de Avaliação Suprainstitucional da Informação Arquivística (ASIA), após definição da metodologia e dos instrumentos de recolha adequados. Neste projeto determinaram-se os prazos de conservação e destino final da informação pública, numa perspetiva transversal. Para os casos de processos de negócio com diferentes soluções de avaliação (por exemplo, com componentes de informação para eliminar e outras para conservar permanentemente, foram criados $4 .^{\circ} \mathrm{s}$ níveis de classificação). Os resultados do Projeto, de natureza incremental, foram incluídos na Lista Consolidada que, assim, passou a integrar também as decisões de avaliação para a informação constante nos processos de negócio da Administração ${ }^{8}$. Com este referencial disponível as entidades públicas podem agora, de modo facilitado, elaborar os seus projetos de elaboração e aplicação de planos de classificação e tabelas de seleção ${ }^{9}$, que podem ser de natureza organizacional ou supraorganizacional, por exemplo, ao nível de ministério/área governativa, da Administração Local ou de uma mesma tipologia (caso das instituições do Ensino Superior). A DGLAB fornece apoio técnico a estes projetos e formação específica, com prioridade para os provenientes de entidades aderentes do PAEIS. Têm

8 Sobre o assunto: <http://arquivos.dglab.gov.pt/programas-e-projectos/modernizacaoadministrativa/macroestrutura-funcional-mef/projeto-avaliacao-suprainstitucional-da-info rmacao-arquivistica-asia> e ainda <http://arquivos.dglab.gov.pt/wp-content/uploads/ sites/16/2017/08/FT2_LC.pdf>.

9 Atualmente a legislação obriga à publicação destas últimas em Portaria de gestão de documentos (PGD's).

66 
ainda procedido à elaboração de manuais de fichas técnicas de apoio à aplicação dos referenciais e instrumentos transversais.

No enquadramento atrás referido, destacamos o caso das instituições do Ensino Superior, que têm vindo a trabalhar com a DGLAB, nos últimos anos, com vista à construção do seu plano de classificação funcional e tabela de seleção, de uso transversal, e à avaliação da documentação acumulada, tendo criado o Projeto Comum de Gestão Documental nas Universidades Portuguesas (sobre este, veja-se Freitas, Corujo, e Sousa, 2015). Espera-se que o esforço desenvolvido permita ultrapassar os efeitos da falta de dinamismo da gestão de documentos na maior parte das instituições universitárias portuguesas, nas últimas décadas ${ }^{10}$.

\subsection{O projeto "Continuidade digital"}

Entre as boas práticas defendidas pela DGLAB para implementar nas entidades da Administração, incluindo as de caráter universitário, contam-se a aplicação de políticas, projetos e procedimentos de preservação digital. O tema, em geral, tem sido objeto de várias pesquisas e publicações com participação académica, salientando-se o trabalho de investigadores da Universidade do Minho (exemplo de Ferreira, 2006, e de Ferreira, Saraiva, e Rodrigues, 2012), da Universidade do Porto (Pinto, 2009), ou do Instituto Superior Técnico (IST), parceiro do projeto e$\mathrm{ARK}^{11}$.

${ }^{10}$ A gestão de documentos nas universidades, nos anos 90, foi objeto de trabalhos e intervenções pioneiras, particularmente devido ao esforço da equipa da Universidade do Porto e da Secção de arquivos universitários da BAD - Associação Portuguesa de Biliotecários, Arquivistas e Documentalistas (veja-se, por exemplo, Ribeiro, 1997). Em eventos públicos, o tema foi retomado, de modo mais visível, apenas em 2013, com o "Workshop - Arquivos Universitários", realizado em Lisboa pela FCSH-UNL, a 4 e 5 de Julho <https://workshoparquivosuniversitarios.wordpress.com>.

${ }^{11}$ Veja-se <http://www.eark-project.com>. 
A DGLAB há vários anos que tem procurado que as entidades da Administração Pública procedam, em primeiro lugar, à elaboração do seu Plano de preservação digital, que tornou obrigatório para todas as que pretendem salvaguardar informação com mais de sete anos de vida, independentemente do destino final. Para o efeito, produziu documento orientador $^{12}$.

Por outro lado, a DGLAB atuou também no desenvolvimento de um arquivo digital, originalmente criado com "capacidade de integrar, gerir e disseminar os objetos digitais produzidos na Administração Pública”, de acordo com a norma ISO 4721:2012 Space data and information transfer systems - Open archival information system (OAIS) - Reference model. Neste contexto, foi criado no final da década de 2000 o Repositório de Objetos Digitais Autênticos (RODA), que viria a ter de ser melhorado posteriormente (veja-se adiante a referência ao RODA +).

Por último, a DGLAB, com o desenvolvimento no Projeto "Continuidade digital", apostou na reunião de representantes de diversas comunidades de prática (exemplo: arquivos, bibliotecas, museus, setor dos audiovisuais e multimédia, jornalismo) com necessidades de gestão e preservação do património digital, com vista à exploração de soluções partilhadas e ao uso de recursos comuns. Procuraram analisar legislação, normas, terminologia, valores, boas práticas (incluindo a prévia avaliação da informação), bem como modelo de custos da preservação digital ${ }^{13}$, de modo a verificar as possibilidades de construção de uma rede comum de preservação de património digital, segundo um modelo distribuído. Entre as propostas a que chegaram encontra-se a constituição de uma rede cooperativa com serviços de armazenamento (quando os organismos

\footnotetext{
${ }^{12}$ Veja-se <http://arquivos.dglab.gov.pt/wp-content/uploads/sites/16/2014/02/Recomend producao_PPD_V2.1.pdf $>$.

${ }_{13}$ Mais informação disponível em <http://1 seminariopreservacaopatrimoniodigital.dglab. gov.pt/projeto-continuidade-digital/documentos-de-projeto>.
} 
aderentes não possuem essa capacidade), preservação, descrição complementar, pesquisa e recuperação de informação, certificação, formação, etc.

Mais recentemente, a DGLAB tem vindo a desenvolver o RODA + , atual plataforma tecnológica dedicada à preservação digital, baseado em tecnologias open source e incorporando, além do modelo OAIS, já referido, as normas EAD, METS e PREMIS, com soluções gizadas à luz de algumas das conclusões do projeto "Continuidade Digital" e orientada para servir a constituição da citada rede comum de preservação ${ }^{14}$.

\section{Que política de gestão de documentos eletrónicos?}

A maior parte das soluções defendidas ou implementadas pelo organismo de coordenação, ao nível da gestão de documentos eletrónicos na Administração, visa ultrapassar, através da adesão voluntária, de orientações e de boas práticas, um problema já há muito identificada no país: a insuficiência do quadro legal em vigor e a falta de políticas e instrumentos de gestão de documentos, particularmente no contexto da Administração eletrónica.

Já em 2012, a DGLAB, em conjunto com a Agência para a Modernização Administrativa (AMA), o IST e outras entidades, produziram um documento intitulado "Modelo de valorização da informação pública" que tinha como objetivo a elaboração de uma Recomendação do Conselho de Ministros (RCM) para aplicação obrigatória na Administração Pública, incluindo a Administração Local. Nele procuraram definir requisitos obrigatórios para qualificar sistemas de arquivo, incluindo os seus sistemas de gestão de documentos (record

\footnotetext{
${ }^{14}$ Cf.<https://roda.arquivos.pt $>$.
} 
systems), com base nas propostas das normas da família ISO 30300, ISO 15489 (em Portugal, NP 4438), nos requisitos do Moreq 2010, etc. Nesse sentido, o documento procurava definir um modelo de governação dos sistemas de arquivo das entidades da AP e identificar responsabilidades na sua gestão, sobretudo dos dirigentes superiores. Incluía ainda os requisitos para uma boa gestão da informação ao nível da captura, registo e descrição, organização, avaliação, armazenamento, recuperação e comunicação, etc. Pressupunha a capacidade de implementar auditorias aos sistemas de arquivo das entidades públicas, a desenvolver pela DGLAB (função que já executa desde 2007). Pretendia obrigar as entidades da Administração, num determinado prazo, a atingir um patamar razoável de gestão de documentos, associado a um modelo de maturidade (exemplo: uso obrigatório do plano de classificação e da tabela de seleção, independentemente da necessidade de eliminar informação pública). Tinha também como pressuposto o uso do MIP e da MEF como forma de assegurar a interoperabilidade semântica. Previa ainda medidas de preservação digital obrigatórias em todas as entidades.

Esta proposta, apesar de nunca ter tido aprovação superior, mantém as bases de outras que mais recentemente têm vindo a ser apresentadas pela DGLAB. A RCM n. ${ }^{\circ} 51 / 2017$, conhecida por "Papel Zero", tem por objetivo a desmaterialização de processos, a promoção da adoção de sistemas de gestão documental eletrónica e a digitalização de documentos de arquivo. Esta RCM apontou um conjunto de medidas que, entre outros aspetos, se pretendem implementar na administração direta do Estado. Determinou que a Direção-Geral do Livro, dos Arquivos e das Bibliotecas (DGLAB), em articulação com a AMA e a Fundação para a Ciência e Tecnologia, apresentasse ao Governo um conjunto de linhas orientadoras para a revisão da legislação arquivística adaptadas "às necessidades decorrentes da desmaterialização de processos e de 
informação". Deveriam contemplar "a) Classificação, avaliação e seleção de informação, tendo em consideração, sempre que possível, os princípios de uma Macroestrutura Funcional (MEF) e a Avaliação SupraInstitucional na Administração (ASIA); b) Esquema de meta informação para a interoperabilidade semântica; c) Preservação do património e da informação digital; d) Aquisição e comunicação de informação integrante do património cultural, científico e tecnológico"; bem como "Mecanismos de monitorização e controlo"15. A proposta da DGLAB tem de efetuar o devido alinhamento com outros diplomas estruturantes, a exemplo da RCM n. ${ }^{\circ}$ 91/2012, que aprova o Regulamento Nacional de Interoperabilidade Digital (RNID), bem como com o Decreto-Lei n. $^{\circ}$ 73/2014, que aprova a plataforma interoperabilidade da Administração Pública (iAP) como meio preferencial de comunicação entre os serviços e organismos públicos. Note-se que no âmbito do projeto piloto desenvolvido em 2016, foi estabelecido o uso obrigatório do MIP e da MEF para a troca e partilha de documentos neste contexto, embora não exista ainda legislação que o obrigue.

Também no âmbito do Programa Simplex +, de simplificação administrativa, está prevista a implementação de uma medida ( . $^{\circ}$ 51) destinada a "utilizar instrumentos transversais de gestão da informação, que visam classificar e controlar os documentos produzidos e recebidos nos organismos públicos. Estes instrumentos serão disponibilizados por uma plataforma modular de serviços partilhados, passível de integração com os sistemas de informação existentes em qualquer organismo. A plataforma permite ainda desmaterializar os procedimentos, atualmente obrigatórios, para se poder eliminar documentação em papel no Estado" "16. A Medida n. ${ }^{\circ} 51$ foi objeto de uma candidatura a

\footnotetext{
${ }^{15}$ A proposta foi apresentada superiormente em meados de agosto de 2017, esperando-se que possa constituir a base de um diploma para a implementação de uma correta política de gestão de documentos eletrónicos na Administração.

${ }^{16}$ Veja-se <https://www.simplex.gov.pt/medidas>.
} 
financiamento comunitário, através do Portugal 2020 / SAMA, com o projeto "Arquivo Digital: Plataforma modular para a classificação e a avaliação da informação pública", devendo a referida plataforma estar disponível em breve. Está previsto, neste contexto, o desenvolvimento de um diploma legislativo, ainda este ano, para suportar a implementação da referida plataforma e a gestão transversal da informação na Administração. Admite-se o cenário das tabelas de seleção terem um processo de aprovação menos complexo e mais célere que as atuais Portarias de gestão de documentos, podendo ser elaboradas através da extração dos resultados da avaliação aplicáveis a cada organismo a partir da Lista Consolidada, via plataforma.

\section{Conclusão}

Apesar dos problemas identificados na gestão de documentos eletrónicos em Portugal, o organismo de coordenação da política arquivística tem procurado implementar propostas para os ultrapassar, entre as quais se salientam os referenciais que permitem a interoperabilidade semântica e o registo e a classificação de documentos (MIP, MEF), bem como a avaliação supraorganizacional da informação pública. Nesse sentido disponibilizou recentemente a nova versão da Lista Consolidada, a partir da qual as entidades podem agora produzir de modo fácil e económico os seus planos de classificação e tabelas de seleção, com o apoio da DGLAB.

Ao mesmo tempo, este organismo procura aproveitar as oportunidades fornecidas pelas políticas de modernização administrativa e, em particular, de desmaterialização, como a Resolução do Conselho de Ministros n. ${ }^{\circ}$ 51/2017, conhecida por "Papel Zero", para efetuar propostas 
de revisão legislativa que permitam atualizar o modo como se efetua a gestão de documentos eletrónicos no país. O objetivo é permitir que o país possa dispor de políticas e soluções inovadoras para a gestão da informação que estejam suficientemente adequadas à nova administração em rede e a um modelo de gestão pública supraorganizacional.

\section{Bibliografía}

Ferreira, M. (2006). Introducão à preservação digital - Conceitos, estratégias e actuais consensos. Guimarães: Universidade do Minho. Recuperado de <https://repositorium.sdum.uminho.pt/bitstream/1822/5820/1/livro.pdf〉.

Ferreira, M., Saraiva, R., e Rodrigues, E. (2012). Estado da arte em preservação digital. S.1.: RCAAP. Recuperado de <http://projecto.rcaap.pt/index.php/ lang-pt/consultar-recursos-de-apoio/remository?func=fileinfo\&id=351>.

Freitas, C., Corujo, L., e Sousa, D. (2015). Projeto comum de gestão documental nas universidades portuguesas: harmonização e estabilização do vocabulário. Em Ligar. Transformar. Criar. 12. ${ }^{\circ}$ Congresso Nacional BAD. Recuperado de <https://www.bad.pt/publicacoes/index.php/congressosbad/article/view/ 1441/pdf_62>.

Lourenço, A. e Penteado, P. (2016). Simplex +: o que precisamos para além da Medida 51?. Em Arquivos Municipais: o que há de novo?. 12. Encontro Nacional de Arquivos Municipais. Recuperado de <https://www.bad.pt/ publicacoes/index.php/arquivosmunicipais/article/view/1535/1465>.

Lourenço, A. e Penteado, P. (2016). Avaliação Suprainstitucional da Informação Arquivística (ASIA): documento metodológico. Lisboa: Direção-Geral do Livro, dos Arquivos e das Bibliotecas. Recuperado de <http://arquivos.dglab.gov.pt/wp-content/uploads/sites/16/2016/03/ASIA_Do c-metodologico2016-03-10.pdf>. 
Lourenço, A. e Penteado, P. (2015). A caminho da ASIA: Avaliação Suprainstitucional da Informação Arquivística Em Ligar. Transformar. Criar. 12. ${ }^{\circ}$ Congresso Nacional BAD. Recuperado de <https://www.bad.pt/ publicacoes/index.php/congressosbad/article/view/1458/pdf_90>.

Lourenço, A., Penteado, P. (2014). Una estrategia para mejorar el acceso y la reutilización de la información pública en Portugal: el papel de la interoperabilidad semántica. Em Girona 2014: Archivos e Industrias Culturales. Recuperado de <http://www.girona.cat/web/ica2014/ponents/ textos/id200.pdf>.

Penteado, P. (2015). Gestão de documentos de arquivo na administração pública em portugal: experiências e desafios. Acervo, 28(2), 121-133. Recuperado de $<$ http://revista.arquivonacional.gov.br/index.php/revistaacervo/article/view/6 $12>$.

Pinto, M. M. (2009). PRESERVMAP. Um roteiro da preservação na era digital. Porto: Afrontamento.

Ribeiro, F. (1997). Gestão da informação no sistema de arquivo da Universidade do Porto. Em Conferência sobre arquivos universitários (pp. 5-11). Recuperado de <http://ler.letras.up.pt/uploads/ficheiros/artigo5411.pdf>.

Martínez Usero, J. Á. (2007). La gestión del conocimiento en la Administración electrónica. Madrid: Arco.

Nota: Para o PAEIS, MIP, MEF, LC, veja-se o site da DGLAB, particularmente $<$ http://arquivos.dglab.gov.pt/programas-e-projectos/modernizacao-adminis trativa>. 


\section{Cuánto cuesta conservar documentos electrónicos: \\ ¿Es posible saberlo?}

\section{José Ramón Cruz Mundet, Carmen Díez Carrera}

UNIVERSIDAD CARLOS III DE MADRID DEPARTAMENTO DE BIBLIOTECONOMÍA Y DOCUMENTACIÓN

\section{Resumen}

El objeto central de esta ponencia es argumentar las dificultades existentes en el cálculo de los costes de la preservación digital, dada la ausencia de un modelo válido. Se analiza la situación actual de la conservación digital y los factores de costes sobre los que existe general acuerdo, para concluir con la incertidumbre que, también en este aspecto, caracteriza al entorno digital.

Palabras clave: Preservación digital; Costes; Modelos de cálculo de costes; Documentos electrónicos; Conservación

Cita recomendada: Cruz Mundet, J. R., y Díez Carrera, C. (2018). Cuánto cuesta conservar documentos electrónicos ¿Es posible saberlo?. En El archivo electrónico en la administración digital: 23 Jornadas de Archivos Universitarios, 21-23 de junio de 2017, A Coruña (pp. 75-82).

DOI capítulo: https://doi.org/10.17979/spudc.9788497496803.075

DOI libro: https://doi.org/10.17979/spudc.9788497496803 
Este texto pretende recoger de la mejor manera posible las palabras pronunciadas en las XXIII Jornadas de Archivos Universitarios organizadas por la Conferencia de Archiveros de Universidades de la CRUE y la Universidade da Coruña. Tales palabras es imposible recordarlas con fidelidad, aunque sí resultará posible acercarse a ellas con la ayuda del hilo conductor de la presentación empleada en los veinte minutos de charla. Por la misma razón, este texto carece de aparato crítico y, en consecuencia, no tiene más crédito que el que las suscribe, en cuanto quien las pronunció, no de su autoría, que lo fue al alimón con la investigadora que acompaña en el encabezamiento y es forzoso reconocerlo en honor a la verdad. Los organizadores se pusieron primeramente en contacto con la profesora Díez, y al coincidir las fechas con otro compromiso académico, lo hicieron con el que encabeza estas líneas.

Queremos expresar, en primer lugar, nuestro agradecimiento a la Conferencia de Archiveros de Universidad de España (CAU), por la gentileza de invitarnos a participar una vez más en sus jornadas, y por darnos la oportunidad de compartir unos días con tan queridos colegas.

\section{En el último cuarto de siglo}

En el último cuarto de siglo se viene produciendo un crescendo en la preocupación de cuantos nos vemos afectados, en un sentido o en otro, por el tema (sector público, empresas, especialistas, instituciones de memoria, investigadores, etc.) acerca de si es posible abrigar la certeza de que conservamos, y lo haremos en el futuro, documentos digitales, de la misma manera que los analógicos. La respuesta es, hoy por hoy, negativa. En efecto, aunque cada vez son mayores los esfuerzos por conservar un 
patrimonio documental digital a largo plazo, y todo parece indicar que el resultado se verá algún día coronado por el éxito, la verdad es que por el momento lo es sólo en parte.

En el último cuarto de siglo se viene produciendo un crescendo en la preocupación de cuantos nos vemos afectados, en un sentido o en otro, por el tema de los costes de la preservación digital, pero en esta ocasión el grupo se reduce notablemente, en el sentido de que casi nadie parece preocupado por saber si es posible conocer con certeza cuánto cuesta guardar para siempre algo (documentos digitales) que parece incompatible con el propio objetivo: siempre. En cualquier caso, la respuesta es rotunda, y no está flotando con el viento. No, no es posible hoy por hoy saber a ciencia cierta lo que nos cuesta conservar, no ya permanentemente, sino a largo plazo, los documentos electrónicos.

En el último cuarto de siglo se viene produciendo un crescendo en la preocupación de cuantos nos vemos afectados, en un sentido o en otro, aunque seamos menos aún, por el tema de que estamos obligados a conservar los documentos electrónicos, con independencia de lo que cueste; de modo que la preocupación aumenta por la imposibilidad o la antítesis: no se puede sostener una actividad a cualquier coste.

\section{De dónde venimos y adónde vamos}

Este tema cae de lleno en las preguntas de la vida, que se atribuyen al genial Woody Allen, aunque sea más que dudosa su autoría: de dónde venimos, a dónde vamos... y cuánto cuesta.

Venimos de un mundo que llaman analógico, de lámparas y tubos de rayos catódicos que tardaban minutos en reproducir una imagen, un mundo lento pero lleno de certezas. Y vamos hacia un mundo digital, de 
inmediatez y también de incertidumbre. En el ámbito archivístico, venimos del papel como soporte por antonomasia de los documentos, indisociable de su contenido, accesible, disponible, legible a ojos vista sin más intermediarios, razonablemente fácil de guardar por siglos. Y vamos a lo digital, entorno donde parecen diluirse los documentos, primero legibles por máquina, luego electrónicos, más tarde digitales, y finalmente subsumidos en el concepto omnicomprensivo, por no decir ambiguo, de activos digitales.

Por lo que nos toca ahora, los activos digitales deben preservarse de modo que permanezcan siendo auténticos, íntegros, fiables, seguros y accesibles. Al menos en lo que respecta a los documentos, condiciones también exigibles a los analógicos, donde la custodia segura preserva la autenticidad, la integridad y, en consecuencia, la fiabilidad de los documentos archivados, que al estarlo son accesibles. Permítasenos un inciso acerca del concepto de documento, que en ocasiones parece que quiere ser dado de baja de la lista. La humanidad conserva información de todo tipo $\mathrm{y}$, siendo digital, lo hace con los mismos medios, con independencia de su naturaleza y finalidad. Pues bien, dentro de ese magma de información, hay una parte que cumple con tres requisitos inexcusables y simultáneos: es una información interna, producida como resultado de procesos que sustentan la actividad de su productor; es además previsible, por cuanto se sabe con antelación el tipo de información que va a contener; y está regulada, pues es resultado de actividades sujetas a normas, como lo está la forma de estructurarse esa información, su régimen de uso, acceso y conservación. Pues bien, esa información digital interna, previsible y reglada es el documento... digital, sea suelto o agrupado en un expediente, como en el papel, o en base de datos como lo ha sido hasta hace poco el formato libro. La contabilidad, los censos, listas... se asentaban en libros, como ahora lo hacen en bases de datos. 
El reto de la preservación digital y, por consiguiente, el de sus costes, se debe a cambios formales y también en la naturaleza de la información. Ya hemos hecho referencia a los derivados de los medios, veamos sucintamente otros de naturaleza más profunda, si cabe. Uno de ellos es la contradicción en los términos que existe entre conservación permanente y medios tecnológicos efímeros por naturaleza. Si permanecer es, según la primera acepción del Diccionario de la Real Academia Española (DRAE), mantenerse sin mutación en un mismo lugar, estado o calidad; y su adjetivo, permanente, lo es sin limitación de tiempo, está claro que resulta imposible respecto de los documentos digitales. ¿Qué es lo que cabe entonces? Creemos honestamente que preservar, o sea, resguardar anticipadamente los documentos electrónicos para evitar daños y peligros. Y una vez dados a la luz, lo que cabe es curar, en el sentido que le da el verbo intransitivo (13. ${ }^{a}$ acepción del DRAE) y en nuestro caso: cuidar de los documentos, poner cuidado en que sigan siendo los mismos, aun habiendo sufrido alguna mutación, y sobre todo que sigan siendo accesibles. Aspecto este en el que la diferencia papel-digital resulta patente. Y este es el fondo del reto digital, mantener los documentos accesibles en el tiempo y que, aun habiendo variado su estado o calidad en algo, continúen siendo auténticos, íntegros, fiables y seguros.

Y estamos obligados a hacerlo en un entorno en el que el factor tiempo, además de gran enemigo de la permanencia, incrementa de manera imparable el volumen a conservar; de modo y manera que a día de hoy la humanidad produce cuatro veces más información de la que puede contener en sus sistemas... lo que conduce a una vida media decreciente de la información. 
Se da la paradoja de que la gestión de unos documentos producidos, usados y conservados por medios tecnológicos, sigue haciéndose de modo manual en gran medida. Sí, los procesos de organización, captura, transferencia y gestión en los repositorios digitales son altamente dependientes de la acción humana directa, hasta el punto de que constituye uno de los principales factores de costes y, por si fuera poco, una de las variables que más hace honor a su apellido. Así, mutatis mutandis, nos vamos acercando al objeto de esta disertación.

\section{Cuánto cuesta}

Desde una fecha tan lejana como 1998, en que Beagrie-Greenstein y Hendley trajeron a colación el planteamiento de los costes, hasta 2015 en que se publicó el modelo 4C (Colaboration to Clarify the Costs of Curation), último de los conocidos, ha habido al menos diez intentos serios y cabales de modelizar los costes de la preservación digital... con otros tantos resultados distintos.

Pero ¿es que resulta tan difícil ponerse de acuerdo para medir una misma realidad? La respuesta es sí, más que difícil parece imposible, porque la realidad es variada. No es lo mismo conservar datos científicos, por más estructurados que estén, que documentos dependientes de su estructura para surtir efectos. Por otra parte, sabemos lo que cuesta almacenar en la nube, por byte o por petabyte, como sabemos que no es lo mismo si la nube es propietaria o un servicio, como que no es igual hacerlo en local que en una red LOCKSS, por ejemplo.

En lo que hay consenso es en los factores de costes, aunque a partir de aquí su peso y valor en el cálculo varían enormemente, como ya hemos tratado en diversos trabajos publicados en los últimos dos años. Dichos factores son, escuetamente expresados: 
1) los costes de desarrollo o de puesta en marcha y el plan de amortización;

2) la infraestructura tecnológica;

3) los costes operativos no laborales (instalaciones, suministros, mantenimiento...);

4) los costes laborales: directos e indirectos;

5) los inherentes a la adquisición o, en nuestro caso, creación de la información;

6) los derechos de propiedad;

7) los seguros;

8) la gestión de riesgos;

9) las pérdidas (datos, documentos); y

10) los costes inherentes a la actividad específica: identificación y selección; transferencia y control; conversión de formatos; descripción/incorporación de metadatos; suministro de medios de acceso; generación, almacenamiento y servicios de copias de acceso.

A partir de aquí, las piezas encajan de forma que dan lugar a distintos y hasta cierto punto incompatibles modelos de costes. La dificultad para llegar a una conclusión de validez general tiene diversas caras. Hay pocas experiencias todavía y, por lo tanto, pocos datos. Además, los datos son difíciles de extrapolar por su diversa naturaleza, de modo que no es lo mismo conservar datos que imágenes, documentos que libros. Los costes dependen también del rango de servicios que se preste. Todo coste debe ser contrastado con su beneficio y, en este caso, muchas veces los beneficios no se pueden monetizar. Sin olvidar que se trata de una actividad de alto riesgo, asociada a elevadas probabilidades de fallos y 
pérdidas. Por último, se trata de una actividad, la conservación, carente de incentivos económicos, de modo que mientras producir sea más barato que conservar, la preservación será difícilmente sostenible.

¿Hay, para concluir, lugar para la esperanza? Según los más optimistas para el 2020 - ¡ah, las fechas emblemáticas!- habremos alcanzado un modelo de costes operativo, aunque posiblemente lo que suceda, por lógico y también deseable, es que, en un problema derivado de la tecnología, sea esta quien lo resuelva. En tal sentido, no parece descabellado aventurar que el desarrollo de la inteligencia artificial y de los sistemas expertos permita adquirir la capacidad de hacer permanente lo que hoy resulta efímero. 
23

jornadas archivos universitarios

experiencias empresa 



\section{Gestión integral del ciclo de vida del expediente y documento electrónico para cumplir con las leyes 39 y 40/2015}

\section{José Ángel Fernández Carrasco}

GuADAlTEl S. A.

\section{Resumen}

La entrada en vigor de las Leyes 39 y 40 de 2015, que regulan respectivamente el procedimiento administrativo común y el régimen jurídico del sector público, establecen un nuevo marco jurídico para las administraciones públicas y entidades del sector público que se encuentren dentro de su ámbito subjetivo, a la hora de prestar sus servicios de forma electrónica. En el contexto de este nuevo marco normativo cobra mayor relevancia el desarrollo de soluciones tecnológicas como G-EDE, creada por Guadaltel S. A., con el objetivo de realizar la gestión integral del documento electrónico a lo largo de su ciclo de vida.

Palabras clave: Administración electrónica; Ley 39/2015; Ley 40/2015; Tecnología; Archivo electrónico único; Gestión documental

Cita recomendada: Fernández Carrasco, J. A. (2018). Gestión integral del ciclo de vida del expediente y documento electrónico para cumplir con las leyes 39 y 40/2015. En El archivo electrónico en la administración digital: 23 Jornadas de Archivos Universitarios, 21-23 de junio de 2017, A Coruña (pp. 83-91).

DOI capítulo: https://doi.org/10.17979/spudc.9788497496803.083

DOI libro: https://doi.org/10.17979/spudc.9788497496803 


\section{Introducción}

Los procesos y procedimientos que se llevan a cabo en las administraciones públicas se soportan principalmente en documentos. Estos recogen las actuaciones, decisiones y resoluciones administrativas, que evidencian el cumplimiento de los distintos pasos de la tramitación.

Las acciones normativas que han ido paulatinamente sentando las bases de la administración electrónica tienen relación directa o indirecta con la documentación administrativa (registro telemático, firma electrónica, etc.). Sin embargo, no es hasta la publicación de la Ley 11/2007 cuando se ponen de relevancia los conceptos de documento electrónico y archivo electrónico. Posteriormente, esta situación se reafirma con la entrada en vigor de la Ley 39/2015, de 1 de octubre, del Procedimiento Administrativo Común de las Administraciones Públicas y la Ley 40/2015, de 1 de octubre, de Régimen Jurídico del Sector Público.

Son necesarias herramientas tecnológicas para el tratamiento archivístico integral de los documentos de una organización, contemplando la gestión informatizada de todo tipo de documentos y expedientes, sean estos electrónicos y/o físicos, y cubriendo todas las fases de su ciclo vital: desde el archivo de oficina hasta el archivo histórico, permitiendo la comunicación electrónica y el traspaso de la información entre ellos.

De acuerdo con lo anterior, el sistema G-EDE de Guadaltel S. A. extiende el modelo de gestión documental tradicional a los documentos electrónicos, tanto los generados durante la tramitación de los diferentes procedimientos administrativos que se producen en cualquiera de los sistemas de información, como los derivados de 
expedientes que se convierten en electrónicos mediante un proceso de digitalización certificada.

El sistema contempla la gestión de un archivo mixto, al asumir tanto la convivencia de documentos electrónicos y de documentos físicos, como las tareas de digitalización de documentos y de trasformación de formatos electrónicos.

\section{Normativa y estándares}

El sistema G-EDE da respuesta a los requisitos normativos, procedimentales y de estándares de aplicación en el campo de la gestión documental electrónica y el archivo (Figura 1).

\section{ib:ede}

¿Por qué G-EDE?

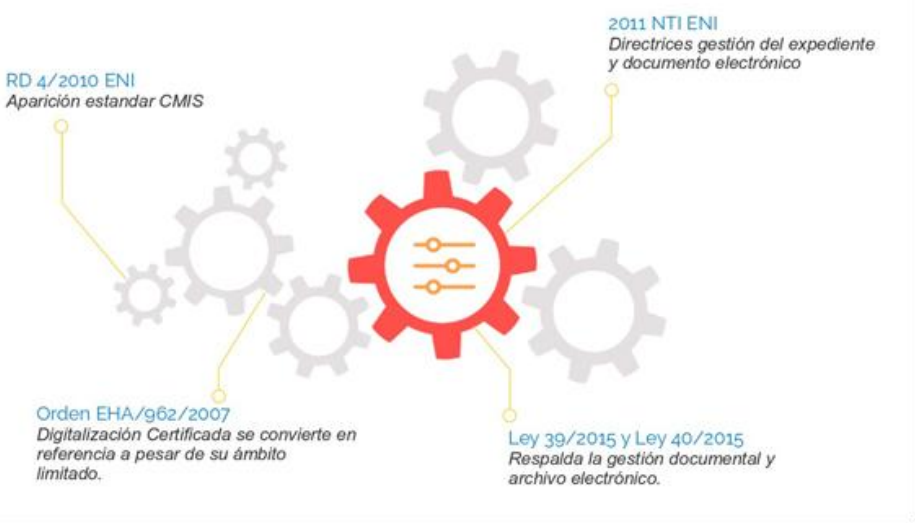

Figura 1. Evolución normativa y nacimiento de G-EDE 
En cuanto a la regulación normativa, se pueden señalar las siguientes referencias a las que el sistema da respuesta:

- Ley 39/2015, de 1 de octubre, del Procedimiento Administrativo Común de las Administraciones Públicas.

- Ley 40/2015, de 1 de octubre, de Régimen Jurídico del Sector Público.

- Real Decreto 4/2010, de 8 de enero, por el que se regula el Esquema Nacional de Interoperabilidad en el ámbito de la Administración Electrónica.

- Real Decreto 3/2010, de 8 de enero, por el que se regula el Esquema Nacional de Seguridad en el ámbito de la Administración Electrónica.

- Ley Orgánica 15/1999, de 13 de diciembre, de Protección de Datos de Carácter Personal.

- Real Decreto 1720/2007, de 21 de diciembre, por el que se aprueba el Reglamento de desarrollo de la Ley Orgánica 15/1999, de 13 de diciembre, de protección de datos de carácter personal.

- Ley 37/2007, de 16 de noviembre, sobre reutilización de la información del sector público.

- Resolución de 19 de febrero de 2013, de la Secretaría de Estado de Administraciones Públicas, por la que se aprueba la Norma Técnica de Interoperabilidad de Reutilización de recursos de la información. 
Durante el desarrollo de la solución se han tenido en cuenta múltiples normas técnicas y estándares de referencia:

- MoReq2 y MoReq2010 (Modelo de requisitos para los sistemas de gestión de documentos electrónicos de archivo): captura de información, sistema de clasificación, valoración para transferencias, gestión de calendario de conservación, medidas de auditoría, trazabilidad y seguridad, búsquedas y recuperación de la información, etc.

- Norma ISO 15489 - Gestión de documentos: referida a los sistemas de gestión documental desde la oficina.

- Norma ISO 14721 - Sistemas de transferencia de datos e información espaciales. Sistema abierto de información de archivo (OAIS).

- Norma ISO 19005 - Gestión de documentos. Formato de fichero de documento electrónico para la conservación a largo plazo (PDF/A).

- Normas internacionales y nacionales para la descripción archivística: ISAD (G), ISAAR CPF, CNEDA, Norma ISO 16175-2:2012, etc.

\section{Tecnología al servicio de la gestión documental y el archivo.}

G-EDE tiene un carácter transversal, puesto que afecta a toda la organización y está involucrada en todos los procesos. Por ello, Guadaltel S. A. orienta su desarrollo hacia su integración con el resto de sistemas de gestión a partir de una capa de interoperabilidad, pero teniendo como premisa que el impacto de dicha integración debe ser el menor posible, con acoplamiento suave. 


\section{e. G:ede}

\section{Valor diferencial de G-EDE}

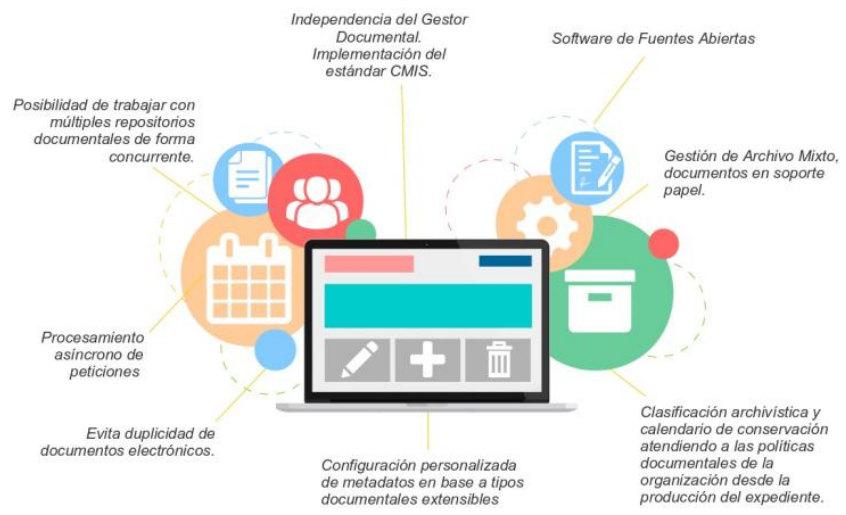

Figura 2. Valor diferencial de G-EDE

Se trata, pues, de una gestión documental integral de y para toda la organización, y que no interfiera en los sistemas de gestión de la organización (Figura 2). No obstante, el sistema permite la evolución en la gestión documental sin afectar a los sistemas de información.

Cuando se quiere conectar una aplicación de negocio con un gestor documental, las organizaciones se ven obligadas a realizar modificaciones tanto en el gestor como en las aplicaciones, de modo que se preparen ambos extremos del canal para poder comunicarse. Por ello, se ha puesto el foco en dotar de independencia al gestor documental gracias a la implementación del estándar Content Management Interoperability Services (CMIS), por ejemplo: Alfresco, Nuxeo, Documentum, etc. De esta manera, se ahorra tiempo y dinero, y se elimina el problema del versionado de los sistemas. 
Al implementar la capa de interoperabilidad con el estándar CMIS se soluciona una parte del problema, la del extremo del gestor. G-EDE se integra con el gestor documental (cualquiera que implemente CMIS), de manera que no haya que realizar modificaciones en él para prepararlo para la comunicación con las aplicaciones.

Además, ofrece todas las funcionalidades sobre expedientes $\mathrm{y}$ documentos electrónicos: foliado del expediente, generación de índices, digitalización de documentos, informes y diligencias de firma, etc. Igualmente posibilita el acceso completo e inmediato a los documentos a través de los metadatos de consulta en línea, lo que permite la visualización de los documentos con todos los detalles de su contenido, la copia o descarga en línea de formatos originales y la impresión de los documentos que sean necesarios. Se aplican en todo momento las medidas de seguridad que garantizan la integridad, autenticidad, confidencialidad, calidad, protección y conservación de los documentos almacenados.

De cara a los expedientes electrónicos, G-EDE permite la creación de índices que actúan como elementos integradores del expediente. Este índice es generado por la propia herramienta, tanto desde las interfaces web como desde el catálogo de servicios; y está compuesto por todos los metadatos del expediente, junto con los documentos que lo componen (metadatos, binario y firmas). Además, el índice se encuentra firmado electrónicamente, lo que permite garantizar la integridad del expediente a lo largo del tiempo. 
Por último, y no menos importante, se han adoptado medidas tendentes a:

- asegurar la conservación de los documentos electrónicos a lo largo de su ciclo de vida, garantizando su recuperación durante el plazo mínimo de conservación establecido en las normas administrativas. El almacenamiento es seguro (archivo securizado). En particular, se aseguran la identificación y el control de accesos de los usuarios, así como cualquier operación que se realice en el sistema, garantizando la trazabilidad de los documentos y expedientes; $\mathrm{y}$

- asegurar el valor probatorio y fiabilidad; evidencia electrónica de las actividades y procedimientos; así como la transparencia, la memoria y la identificación de los órganos de las administraciones públicas y de las entidades de derecho público vinculadas o dependientes de aquellas, que ejerzan las competencias sobre el documento o expediente.

\section{Conclusiones}

Se resumen a continuación los aspectos fundamentales de la aplicación:

- Independencia del gestor documental con el uso del estándar CMIS, con lo que G- EDE puede funcionar con la mayoría de gestores documentales actuales directa y fácilmente.

- Está basado en software de fuentes abiertas, con lo que se minimiza el número de licencias de terceros.

- Posibilidad de gestionar archivos mixtos: de documentación en papel y de la electrónica del archivo de oficina. 
- Clasificación archivística y calendario de conservación, atendiendo a las políticas documentales de la organización, desde la producción del expediente en terceras aplicaciones integradas con G-EDE.

- Configuración personalizada de tantos tipos documentales y metadatos como se necesiten, no limitándose a los descritos en el Esquema Nacional de Interoperabilidad (ENI).

- Análisis de cada fichero que se incorpora, así como su contenido, evitando la duplicidad de ficheros iguales y ahorrando espacio en el gestor documental al permitir que un mismo fichero binario pueda pertenecer a diferentes documentos electrónicos con diferentes metadatos.

- El procesamiento de los expedientes, documentos, operaciones de transferencia, etc. se realiza con tareas asíncronas y programables, que pueden tener lugar en momentos de baja carga del sistema, mejorando los tiempos de respuesta.

- Posibilidad de trabajar con múltiples repositorios documentales, lo que permite reservar ciertos gestores documentales para consulta, sin incorporar nueva información, en el caso de que carezcan de espacio o por un cambio de versión, sin la necesidad de migraciones de datos. 



\section{El papel del archivero frente a la Ley 39/2015: el documento electrónico y su implantación en una universidad: planificación, ejecución y herramientas}

\section{Raül Rabionet i Janssen}

AGTIC Consulting S. L.

\section{Resumen}

La Ley 39/2015, de 1 de octubre, de Procedimiento Administrativo Común de las Administraciones Públicas, introduce un cambio de paradigma al imponer el documento electrónico como único soporte válido de la actuación administrativa. En este contexto, las universidades públicas tienen que planificar una nueva manera de trabajar, centrada en la tramitación de expedientes electrónicos y en la aplicación de los procesos de gestión documental en dicho soporte. Para que este modelo de trabajo sea sostenible a medio plazo, se requiere una planificación corporativa de los nuevos procedimientos y herramientas y el uso de soluciones transversales, en particular para el archivado de la documentación electrónica. Así, el rol del archivero cambia sustancialmente, ya que debe participar en la definición de los criterios, de tal manera que sus recomendaciones se apliquen en el momento en que la documentación se genera, y no solamente cuando se almacena. Trabajando conjuntamente con los responsables tecnológicos, jurídicos y organizativos, podrán definir las metodologías de trabajo que permitirán sacar el máximo beneficio, en términos de eficiencia y automatización de procesos, a estas nuevas herramientas.

Palabras clave: Documento electrónico; Expediente electrónico; Modelo de gestión documental; Política de gestión documental 
Cita recomendada: Rabionet i Janssen, R. (2018). El papel del archivero frente a la Ley 39/2015: el documento electrónico y su implantación en una universidad: planificación, ejecución y herramientas. En El archivo electrónico en la administración digital: 23 Jornadas de Archivos Universitarios, 21-23 de junio de 2017, A Coruña (pp. 93-100).

DOI capítulo: https://doi.org/10.17979/spudc.9788497496803.093

DOI libro: https://doi.org/10.17979/spudc.9788497496803

En la última década, la Administración Pública española ha dado importantes pasos para cambiar su modelo de gestión con el uso intensivo de las tecnologías de la información, mediante cambios legislativos y el despliegue de plataformas y herramientas para la gestión electrónica de la actividad administrativa, promovidas por la administración central y por entes especializados en facilitar este tipo de soluciones.

La Ley 11/2007, de 22 de junio, de Acceso Electrónico de los Ciudadanos a los Servicios Públicos, estableció las principales instituciones jurídicas que permiten una gestión electrónica del procedimiento administrativo, como son la sede electrónica, el registro electrónico y la notificación electrónica. Esta ley fue generalmente conocida como Ley de administración electrónica, pero en la práctica se interpretó y aplicó como una Ley de administración telemática, es decir, la mayor parte de las administraciones la desplegaron creando los mecanismos necesarios para poderse relacionar telemáticamente con el ciudadano, pero prestando poca atención al cambio de sus procesos internos.

Desde el punto de vista archivístico se han desarrollado múltiples estudios que avalan los ahorros en eficiencia y los beneficios organizativos en cuanto a agilidad de la tramitación, accesibilidad y 
seguridad de la información, resultantes de aplicar modelos de gestión basados en documentos electrónicos. La Ley 11/2007 introducía conceptos como el de expediente administrativo electrónico, pero en definitiva no obligaba a su utilización $\mathrm{y}$, por tanto, tuvo un impacto limitado en este sentido.

Cabe decir que el desarrollo normativo que despliega la Ley 11/2007 y, en concreto, el Esquema Nacional de Interoperabilidad y las Normas Técnicas que lo desarrollan, sí definen un entorno de actuación administrativa en el que toda la documentación es electrónica. A partir de estos desarrollos las administraciones más punteras en esta materia, como la Agencia Estatal de Administración Tributaria (AEAT), han llegado al punto de gestionar mucha de su actividad de manera enteramente electrónica.

La Ley 39/2015, de 1 de octubre, de Procedimiento Administrativo Común de las Administraciones Públicas, construye sobre el modelo definido previamente, pero da el impulso final al concepto de expediente electrónico, al establecer (artículo 26) que la actuación administrativa se soporta en documentos electrónicos. Esta obligación entró en vigor el 2 de octubre de 2016. El plazo de vacatio legis de un año podría considerarse breve para un cambio tan profundo, pero hay que tener en cuenta que el legislador parte de la idea de que hemos tenido ocho años para cumplir con la Ley 11/2007, para la cual el documento y expediente electrónicos ya eran elementos necesarios, si bien no excluyentes.

El hecho es que hemos tenido que aceptar que buena parte de la administración pública, también en el ámbito universitario, no hizo todos los esfuerzos necesarios para dar cumplimiento a la Ley 11/2007, y por ello muchos han quedado en una situación difícil con el más reciente cambio legal. La sustitución de la tramitación administrativa tradicional, 
basada en el papel, por una basada en documentos electrónicos, no se resuelve simplemente con el desarrollo de herramientas tecnológicas, sino que requiere de un profundo cambio organizativo que se despliega en cuatro niveles: a parte de las soluciones tecnológicas, se requiere el desarrollo de instrumentos archivísticos y modelos de gestión documental, se requiere un replanteamiento de los procedimientos y metodologías de trabajo y también, por último, la actualización de la normativa interna para dar cobertura a las nuevas herramientas.

Lo que está ocurriendo en muchas organizaciones, también en el ámbito universitario, es que se está llevando a cabo un despliegue apedazado de este cambio de paradigma: se están resolviendo las necesidades a medida que surgen, sin una visión transversal ni una planificación del cambio a nivel corporativo.

De esta manera, es frecuente encontrar herramientas de firma electrónica o sistemas de soporte a la tramitación, que se usan solamente para algunos procesos o de manera aislada en algunos departamentos, pero es poco común el uso eficaz de gestores documentales o de los servicios de interoperabilidad. En muchas administraciones se están produciendo documentos electrónicos sin que exista un plan sobre cómo se van a almacenar y preservar esos documentos en un sistema de archivo seguro.

La principal carencia a la que se enfrentan muchas administraciones es la ausencia de un modelo corporativo de gestión de los documentos electrónicos. Incluso aquellas que, en cumplimiento de la norma técnica de interoperabilidad correspondiente, se han dotado de una política de gestión de documentos electrónicos, lo han hecho desde un punto de vista programático, pero sin definir en concreto cómo aplican los distintos procesos documentales a su documentación electrónica. 
Un Modelo de Gestión de Documentos Electrónicos (MGDE) está formado básicamente por un conjunto de políticas que establecen las normas que se tienen que cumplir en toda la organización a la hora de crear, gestionar y conservar a lo largo del tiempo un documento o expediente electrónico. Es una herramienta dinámica, que tiene que ser definida con la colaboración de los principales agentes de la universidad y evoluciona conforme lo hacen la legislación y la tecnología.

El hecho de no disponer de un MGDE conlleva múltiples riesgos para la universidad:

- pérdida de la validez del documento electrónico, al no existir procesos para la preservación de las firmas electrónicas;

- dispersión y falta de integración de las soluciones tecnológicas;

- crecimiento desmedido del volumen almacenado;

- alta complejidad para gestionar todo el ciclo de vida de la documentación (su almacenamiento, transferencia, eliminación...);

- pérdida de las ventajas que supone la gestión de documentos y expedientes electrónicos, como la reducción de tiempo y de costes o la automatización de procesos;

- incremento de tareas sin valor añadido, como la gestión manual de los documentos electrónicos, el traslado manual de una herramienta a otra, etc.;

- ausencia de herramientas de interoperabilidad o intraoperabilidad;

- imposibilidad de preservar los documentos y expedientes electrónicos; y

- en definitiva, frustración para los usuarios ante las dificultades del nuevo modelo. 
Es fundamental comprender que la elaboración de un MGED debe ser transversal, contar con la involucración de las áreas principales y prever su impacto en el conjunto de la universidad. Así pues, además del servicio de archivo, que es vital a la hora de definir el modelo, será necesario la intervención de los servicios de informática, de responsables de organización y de la secretaría general o la asesoría jurídica (Figura 1).

Para garantizar su flexibilidad y perdurabilidad en el tiempo, conviene ver el Modelo de Gestión de Documentos Electrónicos como un conjunto de instrumentos o instrucciones internas, desplegados en forma de pirámide, cuya cúspide es la política de gestión documental, cuya vocación es de una larga duración, pero que se despliega en una serie de modelos y directrices sobre el ciclo de vida de los documentos, los procesos documentales (descripción, clasificación, acceso, preservación...) y la arquitectura tecnológica.

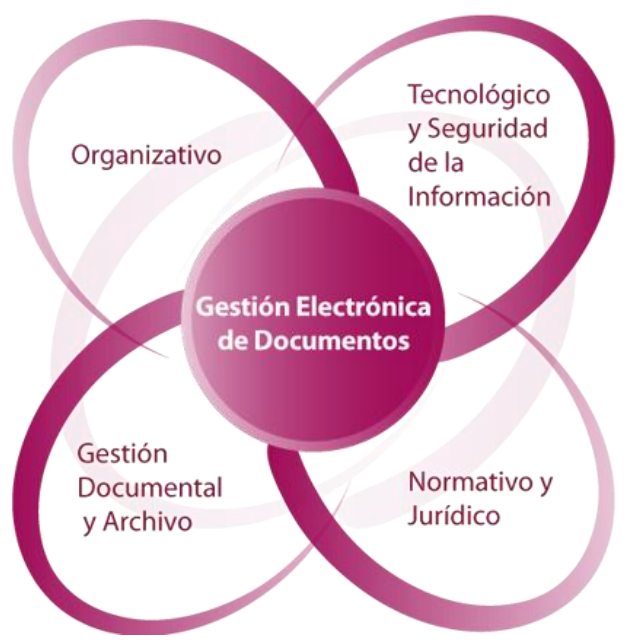

Figura 1. Ámbitos a involucrar en la definición del modelo 
Para hacernos una idea más aproximada, el MGDE debe dar respuesta a cuestiones como: qué formatos documentales se tienen que usar, qué formatos de firma, si queremos un modelo docucéntrico o datacéntrico, qué metadatos son necesarios y cómo se tienen que implementar en el gestor documental, cómo implementar el cuadro de clasificación en el gestor documental, cómo gestionar expedientes híbridos, o cómo generar el índice de los expedientes electrónicos.

Finalmente, el documento y el expediente electrónico implican un gran cambio en funciones que hasta ahora han estado atribuidas a los archivos. Algunas de ellas permanecerán, otras muchas son o serán nuevas y suponen una gran oportunidad para la profesión. Por ejemplo:

- ser el impulsor de la elaboración del MGDE y de la política de gestión del documento y expediente electrónico;

- integrarse en la comisión de gestión documental responsable de la elaboración, mantenimiento y cumplimiento del MGDE y de la política;

- integrarse en la comisión de seguridad;

- ser el responsable funcional de, como mínimo:

○ el gestor documental,

- los instrumentos archivísticos aplicados y

- el archivo electrónico único;

- ser miembro de los grupos de trabajo para la simplificación administrativa, por el importante papel que desempeña el documento electrónico en ella;

- ser el responsable de los expedientes en las fases semiactiva e histórica; 
- ser el responsable de los procesos de migración de formatos, para garantizar la preservación; y

- ser el responsable de los procesos de auditoría del sistema de gestión documental.

AGTIC Consulting SL, en colaboración con la Oficina de Cooperación Universitaria, está ofreciendo a las Universidades un modelo de proyecto de consultoría para abordar este proceso de cambio de manera organizada y establecer los objetivos de desarrollo e implementación de un modelo de gestión documental corporativo. Estos proyectos se construyen en tres fases, tal como se ve en la imagen siguiente, aunque los objetivos concretos se pueden personalizar en función de las necesidades de cada institución.

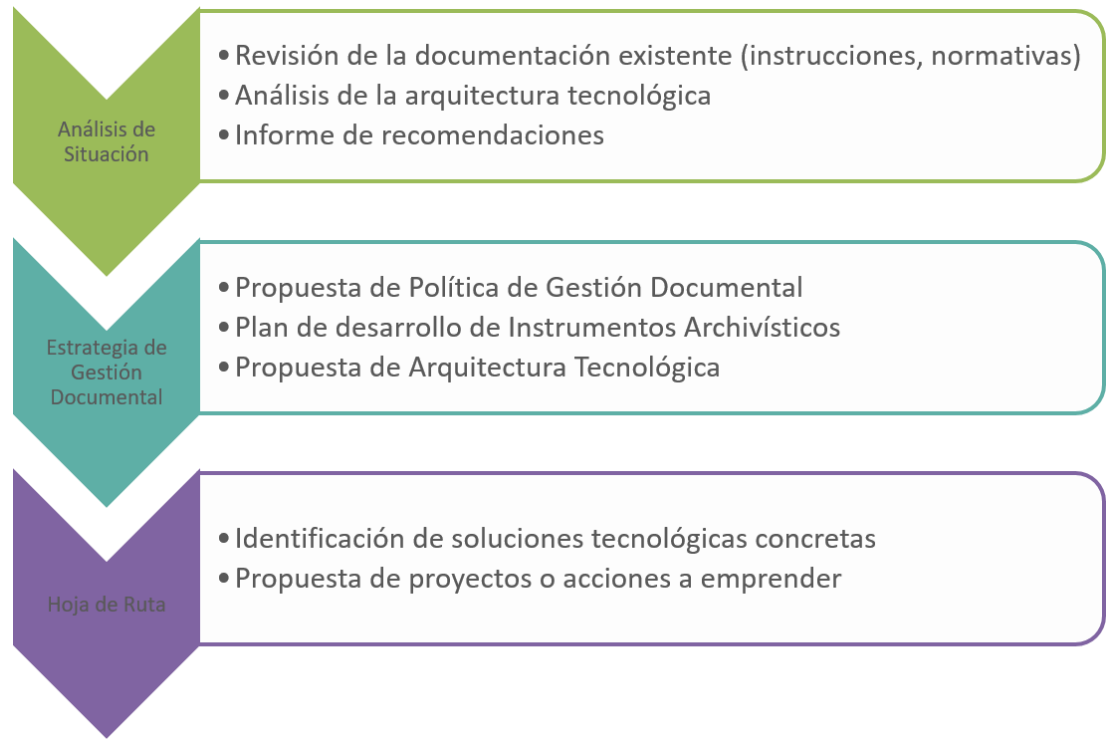

Figura 2. Fases clave del proyecto de consultoría 


\title{
Transición real(ista) al archivo electrónico con Ricoh
}

\section{Mònica Sanyer i Gonzàlez}

\author{
RICOH SPAIN IT SERVICES \\ ÁREA DE CONSULTORÍA DOCUMENTAL
}

\section{Resumen}

Se aborda la gestión del cambio en lo referido tanto a la implantación de la administración electrónica como al archivo electrónico, en el momento de cambio de paradigma impulsado por el establecimiento de la sociedad de la información. Partiendo de la necesidad de adoptar un enfoque que tenga en cuenta la transversalidad de estas realidades, se analizan varios elementos centrales para afrontar la transición: el liderazgo, la planificación de la gestión del cambio, la planificación estratégica, la simplificación administrativa y la integración tecnológica. Se postula la empresa Ricoh como alternativa para su consecución.

Palabras clave: Archivo electrónico; Administración electrónica; Gestión del cambio; Integración tecnológica; Orientación a procesos

Cita recomendada: Sanyer i Gonzàlez, M. (2018). Transición real(ista) al archivo electrónico con Ricoh. En El archivo electrónico en la administración digital: 23 Jornadas de Archivos Universitarios, 21-23 de junio de 2017, A Coruña (pp. 101-105).

DOI capítulo: https://doi.org/10.17979/spudc.9788497496803.101 DOI libro: https://doi.org/10.17979/spudc.9788497496803 
La información es la constante de la razón de ser del archivo: su gestión, conservación y difusión en sus múltiples soportes y formatos, formas y presentaciones. El cambio de paradigma social, de la sociedad de la información, plantea una necesaria revisión del archivo y su transformación.

Asegurar la transformación digital en el archivo significa partir de una realidad actual con condicionantes de ley, de soporte y de formación para asegurar un futuro realista: abierto, transparente, electrónico, funcional e inmediato.

El extenso abanico regulatorio abarca desde la Ley 11/2007, de 22 de junio, de acceso electrónico de los ciudadanos a los Servicios Públicos, hasta la Ley 39/2015, de 1 de octubre, del Procedimiento Administrativo Común de las Administraciones Públicas y la Ley 40/2015, de 1 de octubre, de Régimen Jurídico del Sector Público, pasando por la necesaria Ley 19/2013, de 9 de diciembre, de transparencia, acceso a la información pública y buen gobierno, y la amplia normativa y regulación de carácter técnico. Esta reglamentación plantea un escenario de máximos, frente al que cabe desarrollar un enfoque incremental que considere espacios de transición y transversalidad, cimentados sobre la existencia (y la exigencia) de:

- liderazgo asignado y asumido;

- plan de gestión del cambio, de convicción y capacitación;

- planificación estratégica que aborde proyectos asumibles y sinérgicos;

- simplificación administrativa que optimice procesos erradicando la práctica de su traslación desde el papel; e

- integración tecnológica y reutilización. 
Cabe observar el orden no arbitrario de las dimensiones citadas, considerándose el liderazgo y la gestión del cambio piedras angulares del proceso de transformación hacia el modelo electrónico. Estas dimensiones no han sido siempre suficientemente abordadas, a menudo si consideradas en la teoría, pero trivializadas en la práctica.

\section{Liderazgo}

El compromiso de los agentes implicados en el proceso de transformación se materializa, no únicamente en una política que -entre otros asuntos- nombra equipos, asigna roles y establece competencias y responsabilidades, sino en una comunicación que lo difunde y lo oficializa, publicando la posición que la alta dirección toma y su implicación con el proyecto.

\section{Gestión del cambio}

La transmisión del liderazgo debe conseguir equipos convencidos $-\mathrm{y}$ no solo formados- $\mathrm{y}$ participativos $-\mathrm{y}$ no solo informados-. El nuevo paradigma debe incorporarse al bagaje intelectual de los miembros del equipo para asegurar su adaptación al nuevo modelo; un equipo que debe ser transversal e incorporar a profesionales de todas las dimensiones que integran el archivo electrónico: tecnológica, legal, de negocio y de archivo.

Las actuaciones de gestión del cambio deben considerarse en la génesis de las iniciativas de transformación, y contar con los correspondientes planes de capacitación, de concienciación y de comunicación. 


\section{Planificación estratégica}

El establecimiento tanto del marco organizativo -como reflejo del escenario corporativo (con sus requisitos y riesgos) - como de un marco de referencia objetivo es la base de una planificación realista y sostenida que, en todo caso, ha de contar con la definición de las medidas de control, de auditoría y de mejora que permitan su adaptación, medición y seguimiento.

Una planificación exhaustiva considerará la planificación de la transición, que asegure la operativa con garantía de servicio en el proceso de transformación del archivo.

\section{Simplificación administrativa}

La evolución al nuevo paradigma significa digitalizar y no sólo trasladar desde el entorno papel, significa optimizar y no sólo automatizar.

En esta línea, es necesaria dar una orientación a los procesos que sitúe el análisis de los mismos en la fase previa al análisis documental, y el archivo y la gestión documental ya en el origen de los documentos, asegurando su integración en la operativa del negocio.

\section{Integración}

La integración como elemento vehicular que dinamiza los procesos, adopta en el contexto del archivo distintas consideraciones:

- Integración tecnológica: la presencia de información en la organización se diversifica en aplicaciones y sistemas, exigiendo un modelo de integración que garantice la explotación y 
conservación de la información, de los documentos y los datos, así como su accesibilidad, disponibilidad, integridad y autenticidad.

- Interoperabilidad y reutilización: más allá de la estricta integración tecnológica, la interrelación de modelos, procesos y herramientas es la vía para alcanzar la interoperabilidad y la reutilización, como garantes de optimización y eficiencia del servicio.

El equipo profesional de Ricoh, formado por especialistas en gestión de la información, por consultores tecnológicos certificados en las principales tecnologías de mercado y un equipo de asesores legales, acompaña a las universidades en su camino hacia la administración electrónica y el archivo electrónico con un planteamiento holístico de enfoque consultivo y de implantación, abordando todas las dimensiones necesarias y garantizando el éxito de los proyectos gracias a una dilatada experiencia en el sector. 



\section{Alejandría: archivo electrónico y físico integrado desarrollado para universidades}

\section{Nicolás Manero Carbó}

4TIC

\section{Resumen}

Se presenta Alejandría, plataforma de gestión archivística específicamente pensada para archivos universitarios. Alejandría fue diseñada originalmente basándose en los requisitos del Archivo de la Universitat de Girona, aunque con la intención de que pudiera adaptarse a cualquier universidad española. Con la participación, desde 2016, de cuatro nuevos archivos universitarios, se ha establecido un grupo de trabajo en el que se consensúan las mejoras a implantar. Gracias al trabajo en equipo, durante el año 2017 se han conseguido diversos logros relativos a la homogeneización de políticas y la eficiencia del sistema.

\section{Palabras clave}

Archivo electrónico; Archivo físico; Archivo híbrido integrado; Archivo en universidades; eEMGDE v2; Expediente electrónico; ENI; Depósitos físicos

Cita recomendada: Manero Carbó, N. (2018). Alejandría: archivo electrónico y físico integrado desarrollado para universidades. En El archivo electrónico en la administración digital: 23 Jornadas de Archivos Universitarios, 21-23 de junio de 2017, A Coruña (pp. 107-111).

DOI capítulo: https://doi.org/10.17979/spudc.9788497496803.107 DOI libro: https://doi.org/10.17979/spudc.9788497496803 
La plataforma Alejandría surge de la necesidad del Archivo de la Universitat de Girona (UdG) de poder gestionar todos los depósitos físicos de los que dispone. Su propósito era tener una única aplicación con la que poder controlar toda la documentación archivada, con independencia de su soporte (físico o electrónico). Además, se quería que estuviera adaptada específicamente a las necesidades de una universidad, ya que la mayoría de aplicaciones de gestión de archivo son de ámbito múltiple y no especializadas en el entorno universitario.

Para poder alcanzar el objetivo, la UdG contó con la empresa 4TIC para el análisis de la solución y su posterior desarrollo.

El proyecto se estructuró en 4 fases, teniendo como principal objetivo conseguir un producto especializado para universidades que fuese totalmente integrado:

1. Desarrollar un módulo de gestión de depósitos físicos en el que se incluyera, exclusivamente, la gestión de las estructuras físicas, los elementos de modelado y los contenedores, pero en ningún caso el contenido.

2. Generar un módulo para poder gestionar la documentación electrónica: ficheros, metadatos y tablas de soporte.

3. Desplegar un módulo para poder gestionar la documentación física: metadatos y localización integrada con el módulo de depósitos físicos.

4. Preparar un módulo para poder controlar la retención y el expurgo de toda la documentación de la universidad; además de facilitar la integración con los trámites administrativos online de transferencias, eliminaciones, préstamos, consultas, reactivaciones, devoluciones y prórrogas. 
Durante la primera fase, solamente se habló de estanterías, armarios, cajas, DIN A4 y cintas, y de cómo la UdG podría generar estas estructuras de forma totalmente dinámica y sin depender de proveedores externos en ningún caso.

Se posibilitó la gestión de múltiples depósitos de forma totalmente personalizable y que, con la misma aplicación, se pudiesen obtener informes de ocupación de espacios y reubicar contenedores en cualquier momento.

El desarrollo en esta fase tuvo en cuenta principalmente tres puntos, que se han ido aplicando en las fases posteriores:

- Evitar que la universidad dependiera de entidades externas para poder gestionar la información, y que pudiera así ser plenamente autónoma.

- Diseñar la aplicación pensando en un uso global, de forma que sus usuarios potenciales fueran todas las universidades españolas y, por tanto, sin que fuera personalizada y exclusiva para la UdG.

- Integrar Alejandría con el resto de aplicaciones de la universidad que lo requirieran, gracias a una capa de servicios web.

En la segunda fase se entró de pleno en la gestión de la propia documentación, en este caso la electrónica. Se definieron los objetos documentales a utilizar, la relación entre ellos, los modelos de metadatos a contemplar y, por último, el comportamiento de estos con cada uno de los objetos implicados.

Los objetos documentales definidos fueron los siguientes:

- Fondo

- Clase

- Serie 
- Unidad documental compuesta

- Unidad documental simple

- Volumen

- Documento simple

Se empezó a utilizar una primera versión de esquema de metadatos, definido por la Generalitat de Cataluña y basado en el e-EMGDE. A continuación, se estableció el comportamiento de los metadatos para todos los casos: cuándo eran obligatorios, repetibles o heredables, entre otros.

Al finalizar esta fase, la plataforma ya permitía trabajar con documentación electrónica, insertar sus metadatos, guardar la auditoría de operaciones y obtener las firmas electrónicas de los documentos para guardarlas como metadatos.

En la tercera fase, se continuó con el trabajo realizado en la segunda, pero de forma adecuada a la documentación física. Se ampliaron los metadatos para dar soporte a la localización y el contenido físico. Se integró completamente con el módulo de depósitos físicos, permitiendo saber, por ejemplo, la ubicación de un expediente (en qué estantería o caja está). De la misma forma, desde el punto de vista del depósito, la aplicación marca como "ocupado" el lugar donde está almacenado ese expediente, para evitar, así, poner más documentación en la misma localización.

Finalmente, en la cuarta y última fase del proyecto se analizó y amplió la plataforma con un módulo de gestión de las políticas de conservación y expurgo. De esta forma, se consiguió que no fuera necesario mantener un calendario de conservación independiente. Gracias a esta fase, la plataforma ya dispone de un sistema de avisos que permite informar al archivero/a sobre qué documentación está pendiente, por ejemplo, de eliminar o conservar, y también sobre de qué documentación está en préstamo, en consulta o en transferencia desde la fase activa. 
A finales de 2016 se han unido al proyecto otras cuatro universidades: Universitat de Lleida, Universitat de Vic, Universitat Rovira i Virgili y Universitat Oberta de Catalunya. Con todas ellas se ha formado un grupo de trabajo, de forma que las mejoras o necesidades sobre la aplicación se consensúan conjuntamente. Así, y gracias al trabajo en equipo, durante este año 2017 se han conseguido, entre otros, los siguientes logros:

- Adecuación del modelo de metadatos al e-EMGDE2.

- Generación de índice y expediente electrónico, en formato ENI.

- Aplicación de escritorio para poder sincronizar los documentos con el servidor.

- Exportar la documentación pública para poder publicarla en el portal web o de transparencia.

\section{Conclusiones}

Las principales ideas que se derivan del desarrollo de este proyecto son las siguientes:

- Homogeneización del trabajo entre todas las universidades, bajo unos objetivos y términos legales comunes.

- Reducción de costes.

- Integración en una única plataforma de todas las necesidades de archivo.

- Definición de un roadmap común, adaptado a las necesidades de la universidad española. 



\section{El archivo como pilar del ciclo de vida del documento electrónico. Experiencia de Informática El Corte Inglés}

Carlota Tortosa Gil

INFORMÁTICA EL CORTE INGLÉS

PRoYectos DE ARCHIVO

\section{Resumen}

Se presenta la experiencia de Informática El Corte Inglés en proyectos de desarrollo e implantación de sistemas de gestión de documentos en fase de archivo, con su aplicación ArchiDOC y su evolución, para el Gobierno de Canarias, en su sistema SPERIA, siguiendo la norma OAISISO 14721.

Palabras clave: Gobierno de Canarias; SPERIA; ArchiDOC; Modelo OAIS; ISO 14721; Archivo electrónico único

Cita recomendada: Tortosa Gil, C. (2018). El archivo como pilar del ciclo de vida del documento electrónico. Experiencia de Informática El Corte Inglés. En El archivo electrónico en la administración digital: 23 Jornadas de Archivos Universitarios, 21-23 de junio de 2017, A Coruña (pp. 113-120).

DOI capítulo: https://doi.org/10.17979/spudc.9788497496803.113

DOI libro: https://doi.org/10.17979/spudc.9788497496803 
Las necesidades funcionales que son exigibles a un sistema de gestión de documentos varían en función de la fase del ciclo de vida en que estos se encuentran. De este modo, un sistema de gestión de documentos en fase de tramitación dispondrá de funcionalidades que, en muchos casos, serán muy distintas a las de un sistema de gestión de documentos en fase de archivo.

De forma muy resumida, funcionalidades como la modificación y el borrado de documentos deben permitirse en un sistema de gestión de documentos de trámite y prohibirse en un sistema de gestión de documentos en fase de archivo. Otras funcionalidades como normas de conservación, mantenimiento del contexto y gestión de estructura de clasificación y almacenamiento, solo son obligatorias en los sistemas de gestión de documentos en fase de archivo (por ejemplo, Moreq 2010).

Para garantizar la transparencia y rendición de cuentas del e-gobierno, los documentos electrónicos deben ser auténticos, íntegros y accesibles a largo plazo. Para ello deben contar con pruebas de validación electrónica: firma, sello de tiempo y metadatos.

Los sistemas de gestión de documentos electrónicos deben tener presente las distintas formas en que estos pueden ser creados al:

- ser presentados por los ciudadanos en las oficinas de registro;

- ser producidos por las administraciones por la automatización de la gestión; o

- ser digitalizados: imágenes de documentos analógicos como sustitución de los originales mediante digitalización certificada.

Hay todo un conjunto de normas y estándares internacionales, comúnmente aceptados, que deben cumplir los sistemas que se desarrollan para la gestión de documentos electrónicos. Los más 
destacados -que Informática El Corte Inglés ha incorporado en el desarrollo de su aplicación ArchiDOC-son:

- UNE-ISO 15489: Gestión de documentos.

- MoReq 2010: Modelo de Requisitos para la gestión de documentos electrónicos de. archivo.

- $\operatorname{ISAD}(\mathrm{G})$ : Norma Internacional General de Descripción Archivística.

- ISAAR-CPF: Norma Internacional sobre los Registros de Autoridad de Archivos relativos a Instituciones, Personas y Familias.

- EAD: Descripción Archivística Codificada.

- UNE-ISO 19005: Gestión de documentos. Formato de fichero de documento electrónico para la conservación a largo plazo.

- UNE-ISO 30300: Sistemas de gestión para los documentos. Fundamentos y vocabulario.

- UNE-EN ISO/IEC 27001: Tecnología de la información. Técnicas de seguridad. Sistemas de Gestión de la Seguridad de la Información. Requisitos.

- UNE-ISO 23081: Procesos de gestión de documentos. Metadatos para la gestión de documentos.

Actualmente, y para adaptarse a la Ley 39/2015, de 1 de octubre, del Procedimiento Administrativo Común de las Administraciones Públicas, Informática El Corte Inglés, por encargo del Gobierno de Canarias, está adaptando su sistema SPERIA (basado en la aplicación ArchiDOC) para cumplir el modelo Open Archival Information System (OAIS) que se traspuso en la norma ISO 14721. 
Para facilitar la captura de expedientes electrónicos al sistema de archivo, se van a desarrollar los siguientes componentes:

- Servicio web para crear el índice electrónico de un expediente. Está diseñado para dar servicio a aplicaciones tramitadoras que no dispongan de esta funcionalidad, imprescindible para la gestión de expedientes electrónicos. Este servicio validará de forma automática los metadatos del expediente electrónico y de sus documentos electrónicos, así como los propios documentos electrónicos (existencia, hash y firma correcta), y firmará el índice electrónico creado si la aplicación de tramitación así lo solicita.

- Servicio web para la creación de los Paquetes de Información de Transferencia (PIT). El proceso de captura de la norma OAIS implica que las aplicaciones tramitadoras envíen a la de archivo los expedientes electrónicos en forma de PIT. Este servicio web está diseñado para atender a aquellas aplicaciones que no dispongan de esta funcionalidad. Este validará de forma automática:

- el expediente finalizado con todos sus documentos electrónicos firmados y metadatos;

- el formato de los documentos electrónicos. Se contrastarán estos formatos con una relación de formatos aceptados/rechazados y se suministrará un servicio de conversión de formatos; $y$

- la existencia del índice electrónico, la validez de su firma y sus metadatos.

Una vez superadas estas validaciones, compondrá el XML en formato METS (Metadata Encoding and Transmission Standard), generará y almacenará el PIT, y lo incorporará a su relación de entrega (serie y órgano productor). 
El resultado de estas acciones será comunicado al sistema tramitador desde el que se le invocó, ofreciéndole así mismo la posibilidad de consulta de estado de generación de sus PIT.

- El proceso de captura a desarrollar, según la norma OAIS, mediante el que se incorporan los PIT al sistema de archivo, se compondrá de:

- Cotejo manual por parte de los archiveros: verificación de los metadatos del expediente electrónico, apertura de sus documentos electrónicos y verificación de sus metadatos, revisión del índice electrónico y aceptación o rechazo del PIT.

- Conversión de los PIT a PIA (Paquete de Información de Archivo) e indexación de metadatos en el sistema de información. Para ello se creará un nuevo XML, al que se añadirán los metadatos necesarios para gestionar, preservar, acceder y representar los documentos a lo largo del tiempo, incluyendo los documentos electrónicos correspondientes. Se firmará con el sello electrónico del órgano responsable y se almacenará en el sistema de gestión de documentos electrónicos en fase de archivo.

- Finalización, de forma manual por los archiveros, de la relación de entrega una vez finalizado el cotejo de todos sus PIT.

Asimismo, se desarrollará la funcionalidad de creación de los Paquetes de Información de Consulta (PIC) para permitir la consulta de expedientes electrónicos de archivo a productores e interesados. Los PIC se crearán como consecuencia de una solicitud de consulta, que podrá ser revisada por los archiveros en aquellos casos en los que el solicitante no sea el órgano productor del expediente. En estas situaciones será el personal del archivo el que indique los documentos y metadatos que van a componer el PIC. Además, se creará y firmará el índice electrónico correspondiente al PIC (Figura 1). 


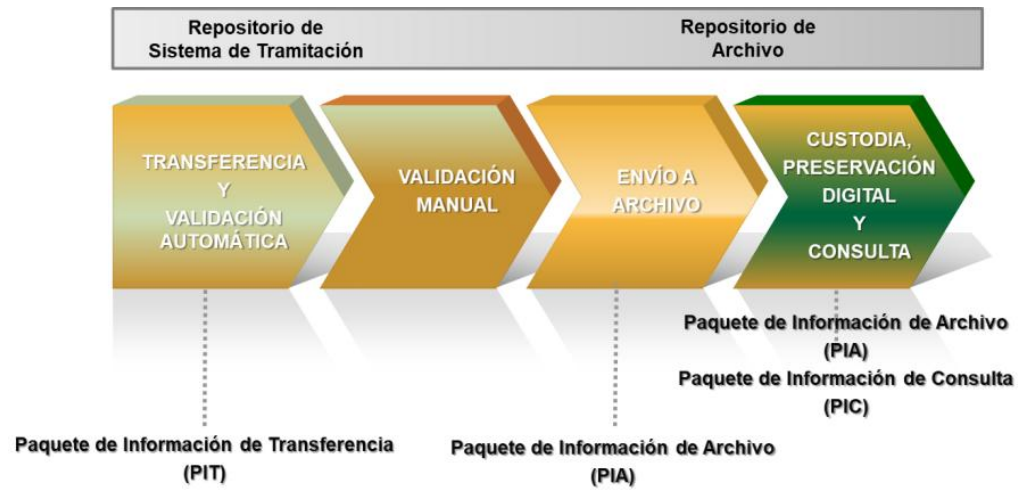

Figura 1. Modelo operativo que ArchiDOC va a seguir en su adaptación para el sistema SPERIA del Gobierno de Canarias.

En el proceso de preservación digital, el sistema de gestión de documentos electrónicos en fase de archivo se dotará de herramientas de administración de formatos, mediante las que se pueda gestionar la obsolescencia de estos con la conversión de los documentos a nuevas versiones, garantizando de este modo su acceso a largo plazo. Así mismo, se dispondrá de mecanismos de comunicación con los usuarios del sistema de gestión de archivo. Estos les informarán de las tareas a realizar como consecuencia de las políticas de eliminación de documentos (expurgo), de obsolescencia de formatos (cambio de formato) y de caducidad de firma (refirmado, re-sellado); así, el usuario podrá priorizar y programar las tareas a realizar automáticamente por el sistema. 


\section{Bibliografía}

Asociación Española de Normalización y Certificación. (2015). UNE-ISO 14721 Sistemas de transferencia de datos e información espaciales. Sistema abierto de información de archivo (OAIS). Modelo de referencia. Recuperado de <http://www.aenor.es>.

CCSDS Secretariat (2012). Reference Model for an Open Archival Information System (OAIS). Recommended practice (CCSDS 650.0-M-2). Magenta book. Recuperado de <https://public.ccsds.org/pubs/650x0m2.pdf >.

Dirección de Tecnologías de la Información y las Comunicaciones. (2016). Esquema de Metadatos para la Gestión del Documento Electrónico (eEMGDE) versión 2.0: documentación complementaria a la Norma Técnica de Política de gestión de documentos electrónicos. Recuperado de $<\mathrm{http}$ ://administracionelectronica.gob.es>.

Dirección de Tecnologías de la Información y las Comunicaciones. (2016). Guía de aplicación de la Norma Técnica de Interoperabilidad de Documento Electrónico. Recuperado de <http://administracionelectronica. gob.es>.

DLM Forum. (2010). MoReq2010 Specification v1.1. Recuperado de <http://www.moreq.info/specification>.

Ministerio de Hacienda y Administraciones Públicas. (2016). Política de gestión de documentos electrónicos MINHAP (2. ${ }^{a}$ ed.). Recuperado de $<\mathrm{http} / / /$ www.minhafp.gob.es>.

Orden de 23 de febrero de 2015, por la que se aprueba la Política de gestión de documentos electrónicos y archivo electrónico de la Administración Pública de la Comunidad Autónoma de Canarias. Canarias. Boletín Oficial de Canarias, 27 de febrero de 2015, núm. 40, pp. 4309-4328. Recuperado de <http://www.gobiernodecanarias.org/boc/2015/040/001.html>. 
Orden de 21 de noviembre de 2013, por la que se aprueba el esquema de metadatos en el ámbito de la administración electrónica de la Administración Pública de la Comunidad Autónoma de Canarias. Canarias. Boletín Oficial de Canarias, 29 de noviembre de 2013, núm. 40, pp. 43094328. Recuperado de <http://www.gobiernodecanarias.org/boc/2013/231/ 001.html>. 


\section{Preservación de activos digitales: \\ el seguro digital definitivo}

\section{Roberto González Siguero}

PIQL SPAIN

DesarRollo DE NeGocio

\section{Resumen}

La gran cantidad de información digital disponible en estos momentos requiere por parte de las instituciones archivísticas una política de preservación a largo plazo que asegure el acceso y uso futuro de los activos digitales. En este trabajo se presenta una solución de preservación digital que aprovecha las virtudes del soporte película para asegurar dicho acceso, del mundo digital para la explotación de los recursos digitales y de un archivo con frío natural para su conservación. Basado en el estándar de preservación OAIS, el sistema permite la gestión integral de los activos a preservar, y asegura el acceso futuro (hasta 500 años) con su tecnología bits on film abierta e independiente de los fabricantes.

Palabras clave: Preservación digital; Microfilm digital; OAIS; Open source; Seguridad de los datos

Cita recomendada: González Siguero, R. (2018). Preservación de activos digitales: el seguro digital definitivo. En El archivo electrónico en la administración digital: 23 Jornadas de Archivos Universitarios, 21-23 de junio de 2017, A Coruña (pp. 121-127).

DOI capítulo: https://doi.org/10.17979/spudc.9788497496803.121

DOI libro: https://doi.org/10.17979/spudc.9788497496803 


\section{Introducción}

En la época actual, en la que se manejan cantidades enormes de información digital, se hace muy difícil conseguir la conservación de esta producción intelectual para que pueda ser utilizada de nuevo en el futuro. Los activos digitales son frágiles (Termens, 2013) y no podemos optar por no hacer nada como en el mundo analógico, almacenarlos en un depósito y esperar que la falta de interacción humana permita recuperarlos en su estado original. En el caso de los datos digitales se necesitan actitudes proactivas para asegurar el acceso futuro.

Además, es necesario asegurar la autenticidad e integridad de los datos, puesto que la facilidad de edición de los mismos puede provocar pérdidas de información, sea de forma consciente, por error, por negligencia o por una acción externa (virus u otros).

Por último, no solo es necesario asegurar el acceso futuro sino también la experiencia y uso actuales. Por ejemplo, de nada sirve almacenar un fichero de texto con formato si en el futuro el usuario no pudiera reproducir los mismos formatos, imágenes, tablas, etc. que contuviera, puesto que dan información adicional que es valiosa para la interpretación.

Este problema no es nuevo y muchas personas implicadas en el mundo digital llevan tiempo avisando de la necesidad de tomar consciencia de la necesidad de la preservación de cualquier tipo de información digital. Uno de ellos es Vint Cerf, vicepresidente de Google, que en sus múltiples conferencias y artículos menciona el peligro de pérdida de información en el que nos encontramos (Sample, 2015).

Por todo esto, la empresa noruega Piql inició en 2007 varios proyectos de investigación para la aplicación de tecnología audiovisual (en concreto película de $35 \mathrm{~mm} \mathrm{~b} / \mathrm{n}$ ) para la preservación de información digital de 
cualquier tipo, aprovechando las buenas características del soporte respecto a varios de los problemas, a saber, longevidad, autenticidad e integridad (Plata y Bjerkestrand, 2012; Drake y Brudeli, 2014).

Este proceso culminó en 2014 con la publicación del informe técnico por parte de Technicolor para confirmar la viabilidad del producto en la conservación de cualquier tipo de información digital y su puesta en el mercado.

\section{Solución de Preservación Piql}

La solución Piql está basada en el uso de una película de poliéster de $35 \mathrm{~mm}$ con emulsión de haluros de plata, en la que se imprime un código de barras 2D que es el encargado de almacenar la información digital. Este código de barras permite la preservación de cualquier tipo de datos digitales, documentos, sonido, vídeo y bases de datos entre otros.

La elección del soporte film se hizo por sus buenas características de longevidad, que han sido probadas por laboratorios independientes, certificando (según normas ISO 18901, 18936 y 18924) la recuperación de la información dentro de 500 años en condiciones normales de temperatura y humedad. Además, es un medio realmente offline que no utiliza energía para la conservación, y es a prueba de piratería puesto que no es modificable (Figura 1).

Para la lectura solamente se requiere una fuente de luz y un sensor capaz de convertir luz en señales digitales, ambos ya están disponibles en el mercado. Piql ofrece una solución incluyendo estos elementos, pero no es necesario que se utilice la tecnología Piql, puesto que los sensores de otros fabricantes son igualmente válidos para la obtención de los fotogramas. Con los fotogramas escaneados y mediante un software de 
fuentes abiertas (que además está escrito en la película) es posible obtener el fichero original que se escribió.

Como puede observarse, requiere de poca tecnología y además es directamente legible por las personas.

Para facilitar la interpretación futura de los datos, la propia película incluye una parte en formato visible, que describe el formato del código de barras, metadatos, el software de decodificación, instrucciones para la decodificación de los datos y cualesquiera otros que faciliten el acceso a alguien que no conozca el contenido. Esta información puede adaptarse a las necesidades del usuario (Figura 2).

Aunque el aspecto más novedoso de la solución Piql es el soporte, el sistema incluye un entorno completo IT (Information Technologies) en el que se facilita la gestión diaria de los activos a preservar. Dispone de un buscador sobre los metadatos definidos y, si el activo está offline, permite realizar su recuperación desde la película. Además, dispone de API (Application Programming Interface) de integración con otros sistemas para la introducción y recuperación de la información. Por último, permite controlar y definir las operaciones previas al envío de la información a la película, como son la normalización de formatos, verificación de los mismos, antivirus, introducción automática de metadatos y otros, para facilitar el día a día a los usuarios.

Otro aspecto importante de la solución es la seguridad de los datos almacenados. El Centro de Investigación de la Defensa de Noruega ha realizado un análisis de la solución Piql frente a las amenazas de la ciberguerra actual, llegando a la conclusión de que es una solución muy interesante para la conservación de información valiosa. Las características fundamentales de la solución en el ámbito de la seguridad son el almacenamiento desconectado, el sistema de archivo automatizado, 
la no necesidad de migración, la longevidad y la confiabilidad de los materiales en los que se basa el archivo (Norwegian Defence Research Establishment, 2016).

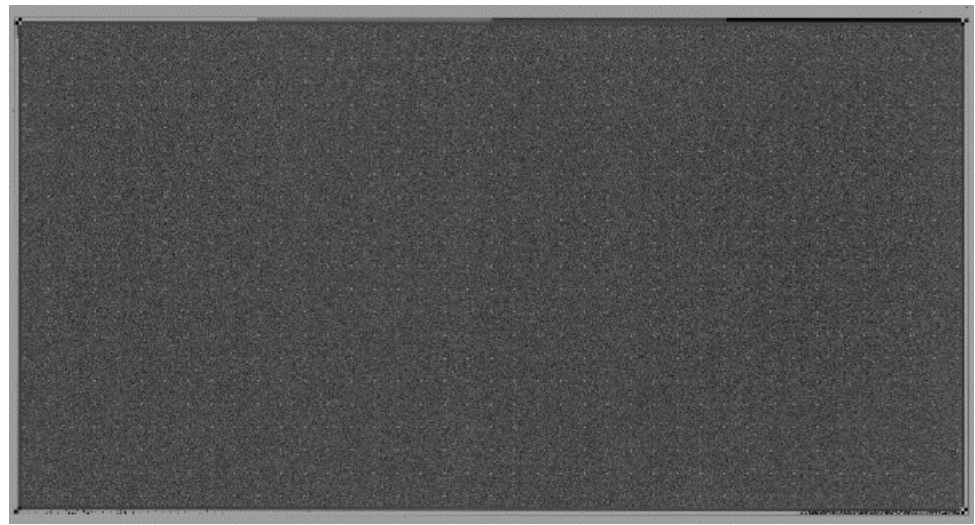

Figura 1. Fotograma en piqlFilm

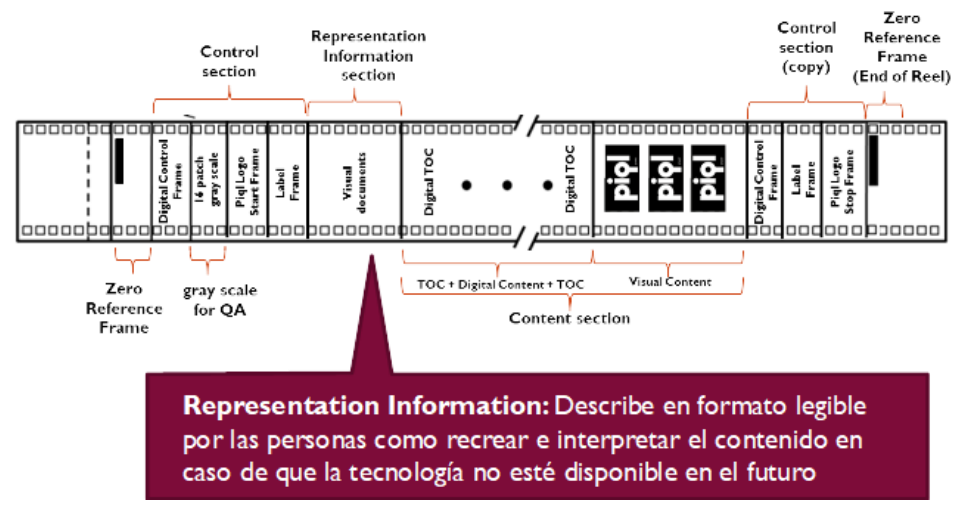

Figura 2. Información de representación 
Por último, como se ha mencionado anteriormente, las condiciones de almacenamiento de la película para su conservación durante 500 años no necesitan ser especiales. No obstante, si la temperatura y humedad del lugar son óptimas, ese tiempo se prolongará. Por ello se ha creado el Archivo Ártico Mundial en las Islas Svalbard para el almacenamiento de las películas en unas condiciones naturales de frío y baja humedad que permitan ampliar el tiempo de conservación, igualmente, se garantiza la seguridad frente a desastres naturales, eventos nucleares y otros sucesos, puesto que se ubica en una mina abandonada a $300 \mathrm{~m}$ por debajo del suelo. Adicionalmente, las Islas Svalbard están protegidas por el Tratado de Spitsbergen de 1920, por el que los firmantes pueden acceder a los recursos de las islas, entre los que se encuentra el archivo.

\section{Conclusiones}

La solución de preservación Piql asegura la autenticidad de la información digital con un medio inalterable, asegura el acceso futuro a través de un formato auto-contenido y tiene una longevidad probada para 500 años en un sistema compatible con el modelo de preservación OAIS. Además, puesto que no requiere intervenciones posteriores para la conservación, constituye un modelo sostenible económicamente en el tiempo y muy respetuoso con el medio ambiente. 


\section{Bibliografía}

Drake, K. M., y Brudeli, B. H. (2014). A holistic approach to digital preservation. Archiving 2014 final program and proceedings, 2014: 79-83.

Norwegian Defence Research Establishment (2016). A risk assessment of the Piql preservation services. Recuperado de <https://www.ffi.no/no/ Rapporter/16-00707.pdf>

Plata, O. y Bjerkestrand, R. (2012). The archivator: a solution for long-term archiving of digital information. Archiving 2012 final program and proceedings, 2012: 70-74.

Sample, I. (2015, Febrero). Google boss warns of 'forgotten century' with email and photos at risk. The Guardian. Entrevista a Vint Cerf. Recuperado de $<$ https://www.theguardian.com/technology/2015/feb/13/google-boss-warnsforgotten-century-email-photos-vint-cerf $>$.

Termens, M. (2013). Preservación digital. Barcelona: Universitat Oberta de Catalunya. 
23

jornadas

archivos

universitarios

conclusiones 


\section{Conclusiones de las XXIII Jornadas de Archivos Universitarios (A Coruña, 2017)}

1. La implantación del archivo electrónico exige actuaciones pensadas para el mundo digital con herramientas adecuadas. El ciclo completo del documento empieza desde que se crea hasta que se conserva a largo plazo. En caso contrario puede producirse una pérdida importante de patrimonio documental.

2. La preservación y conservación digital forma parte de ese ciclo. De manera que paulatinamente los procesos de gestión de documentos y archivo se integran transversalmente en nuestras organizaciones e instituciones universitarias y por tanto permiten una mejor gobernanza para proveer accesibilidad, seguridad, integridad, autenticidad y fiabilidad de los documentos al ser evidencia de actuaciones sobre las que es necesario rendir cuentas.

3. Nuestro principal potencial cuando se habla de archivo único está en proporcionar tratamiento, acceso y recuperación de la información de los documentos en el proceso de gestión y memoria de la Universidad.

4. La normalización de estos procesos de gestión de documentos y archivo es un recurso necesario en el sistema de gestión para el ciclo de vida de los documentos de la Universidad.

5. Una buena política de preservación y conservación pasa por una previa identificación y valoración de lo que conviene conservar. En este sentido, el mundo analógico y el mundo digital coinciden.

6. Los archivos tienen la responsabilidad por lo que respecta a la conservación y preservación en una gestión administrativa eficiente, como garante de los derechos de los ciudadanos. 
